\title{
The Rationale for Exempting Nonprofit Organizations from Corporate Income Taxation*
}

\author{
Henry Hansmann†
}

\section{Introduction}

Although most types of nonprofit corporations have been exempted from the federal corporate income tax since that tax was first adopted, ${ }^{1}$ we continue to lack a clear rationale for the exemption. This was perhaps understandable and acceptable when the nonprofit sector was small and nonprofit organizations were engaged largely in activities of a traditionally charitable nature. Today, however, the nonprofit sector represents a substantial and growing share of the national economy. ${ }^{2}$ Large concentrations of nonprofits can be found in a number of vital and expanding service industries, including education, health care, research, the media, and the arts. Nonprofit firms now commonly provide goods and services in direct competition with profit-seeking firms, and in many cases increasingly resemble their for-profit competitors in their manner of organization and operation. ${ }^{3}$ The traditional criteria for applying the exemption are, as a result, being stretched beyond recognition, so that the absence of an underlying rationale for those criteria, and indeed for the exemption in general, is becoming increasingly conspicuous. To be sure, various efforts to

* Preparation of this Article was supported by a grant from the Program on Non-Profit Organizations at the Institution for Social and Policy Studies, Yale University.

An earlier and somewhat different version of this Article was presented at a meeting of the Committee On Urban Public Economics and is forthcoming, under the title "Why Are Nonprofit Organizations Exempted From Corporate Income Taxation?," in the published proceedings of that conference, ThE INTERAction of THE PUblic, PRIVATE, AND NON-Profit SECTORS (M. White ed. 1981).

For helpful comments I am indebted to, among others, Robert C. Clark, Russell Osgood, A. Mitchell Polinsky, Stanley Surrey, Alvin Warren, and Michelle White.

$\dagger$ Associate Professor of Law and Public Policy, University of Pennsylvania.

1. See Bittker \& Rahdert, The Exemption of Nonprofit Organizations from Federal Income Taxation, 85 YALE L.J. 299, 301 (1976).

2. The best data available, which are not very good, suggest that the nonprofit sector today accounts for roughly $3 \%$ of GNP, compared to just over $1 \%$ fifty years ago. Hansmann, The Role of Nonprofit Enterprise, 89 YALE L.J. 835, 835 n.1 (1980).

3. This is true, in particular, of "commercial" nonprofits, such as nursing homes, day care centers, hospitals, and publications, which are discussed at p. 59 infra. See Hansmann, supra note 2, at 862-68. 
rationalize the exemption have appeared from time to time. The most comprehensive and thoughtful of these efforts is presented in a relatively recent article by Bittker and Rahdert. ${ }^{4}$ But for a number of reasons the Bittker and Rahdert analysis, like its predecessors, ${ }^{5}$ is ultimately unsatisfying.

This Article surveys the various theories that have previously been offered to justify the exemption of nonprofit organizations from income taxation, and discusses the difficulties that those theories present. It then proceeds to offer a novel, and more satisfying, justification for the exemption. In particular, the Article argues that the best justification for the exemption is that it helps to compensate for the constraints on capital formation that nonprofits commonly face, and that such compensation can serve a useful purpose, at least for those classes of nonprofits that operate in industries in which, for various reasons, nonprofit firms are likely to serve consumers better than would profit-seeking firms.

Although exemption from federal income taxation extends to nonprofit organizations that assume a variety of legal forms, including charitable trusts and unincorporated associations, the discussion here will be confined, for simplicity of exposition and analysis, almost exclusively to nonprofits that are incorporated. Since nearly all nonprofits of any financial significance are incorporated, this is not a serious limitation. ${ }^{6}$ Furthermore, the focus here will be largely on the exemption as it is applied to the primary activities of nonprofit organizations; relatively little will be said about the related issue of taxing, as is now done, an exempt nonprofit's income from wholly-owned businesses that it operates at a profit primarily to earn income with which to finance its other activities. ${ }^{7}$ Finally, although a few comments will be offered about exemption from other types of taxes, such as property taxes and sales taxes, the analysis will generally be confined strictly to income taxation, which presents relatively distinct issues.

It should be emphasized as well that the concern here is with the exemption from taxation of the income of nonprofit organizations themselves and not with the charitable deduction, which allows an individual who

4. Bittker \& Rahdert, supra note 1. See also Bittker, Churches, Taxes and the Constitution, 78 YALE L.J. 1285 (1969), which presents a substantially similar analysis.

5. E.g., Stone, Federal Tax Support of Charities and Other Exempt Organizations: The Need for a National Policy, 1968 U. SO. CAL. TAX INST. 27.

6. A few substantial nonprofits, including several of the larger grant-giving private foundations, have been established as charitable trusts rather than as nonprofit corporations. If such organizations were to be denied exemption, there would be a question of the tax rate to be applied. Should they be taxed in the same way as private trusts, or rather as if they were corporations? In any event, the basic issues are the same as for the incorporated nonprofits that are the focus of the following discussion.

7. I.R.C. $\$ 511$ (tax on "unrelated business income"); I.R.C. $\$ 502$ (tax on income from "feeder" organizations). 
makes a contribution to a qualifying nonprofit to deduct the amount of that contribution from his or her income when computing personal income tax. ${ }^{8}$ As the discussion below emphasizes, ${ }^{9}$ the charitable deduction and the exemption raise different issues, and it would be quite conceivable for the tax system to embrace one without the other.

Any discussion of the corporate income tax exemption for nonprofits is handicapped by the lack of consensus concerning the purposes and the consequences of the corporate tax even as it applies to ordinary business corporations. ${ }^{10}$ Indeed, today the confusion concerning the effects of the corporate income tax is so great, and the critics of that tax so numerous, that one might well ask why we apply a separate tax to corporate income at all, and not just why some kinds of corporations are exempt from the tax. At present, however, the corporate income tax seems well entrenched. Consequently, the discussion that follows will take the existence of the corporate income tax as it applies to business corporations for granted and will simply ask whether it makes sense to exempt some or all nonprofit corporations from that tax. As we shall see, ${ }^{11}$ the answer to that question is only partially dependent on the theory one accepts concerning the consequences of the tax as it applies to business corporations.

Much of the discussion in this Article is presented in economic terms, as is appropriate for the subject at hand. Most of the technicalities are, however, relegated to an Appendix, which presents a simple mathematical model supporting and illustrating some of the arguments presented in the text.

\section{The Nature of Exempt Organizations}

It is helpful to begin analysis with a clear image of the essential characteristics of nonprofit corporations and of the exemption from income taxation that applies to them.

A nonprofit organization is, in essence, an organization that is prohibited from distributing net earnings to individuals, such as officers, directors, or members, who exercise control over the organization. In the case of an incorporated nonprofit this "nondistribution constraint" is imposed by the state nonprofit corporation law under which the organization is formed. A nonprofit organization is not, it should be noted, prohibited from earning a profit; in fact, many nonprofits show substantial annual net earnings. All net earnings, however, must be plowed back into financ-

8. I.R.C. $\$ 170$.

9. P. 71 infra.

10. See, e.g., C. MCCLURE, MUST CORPORATE INCOME BE TAXED TWICE? (1979); Stiglitz, Taxation, Corporate Financial Policy, and the Cost of Capital, 2 J. PUB. ECON. 1 (1973).

11. P. 85 infra. 
ing the goods or services that the nonprofit was formed to provide. ${ }^{12}$

Not all nonprofit corporations are exempt from the federal corporate income tax. Rather, only nonprofits that are exclusively dedicated to particular purposes are exempt. The purposes that qualify nonprofits for exemption are explicitly listed in Section 501(c) of the Internal Revenue Code. ${ }^{13}$ Any nonprofit corporation whose purposes do not come within this list is, like a business corporation, subject to income taxation. ${ }^{14}$ The list of qualifying purposes is extensive, however, and has been broadly interpreted. As a result, there are few significant classes of nonprofit corporations that do not benefit from the exemption. ${ }^{15}$ Indeed, the repeated and unreflective reinterpretation of the exemption to accommodate new forms of nonprofit activity, ${ }^{16}$ which has kept the scope of the exemption

12. See Hansmann, supra note 2, at 838 . For an extensive discussion of the application of the nondistribution constraint under current law, see Hansmann, Reforming Nonprofit Corporation Law, 129 U. PA. L. REV. 497 (1981).

13. I.R.C. $\S 501$ (c) extends exemption to, for example, nonprofit organizations "organized and operated exclusively for religious, charitable, scientific, testing for public safety, literary, or educational purposes ..." (\$501(c)(3)); "[c]ivic leagues or organizations . . . operated exclusively for the promotion of social welfare..." (§501(c)(4)); "[l]abor, agricultural, or horticultural organizations . . ." ( $\S 501(\mathrm{c})(5))$; "[b]usiness leagues, chambers of commerce, real-estate boards, boards of trade, or professional football leagues . .." $(\S 501(c)(6))$; "[c]lubs organized for recreation for] pleasure . .." (§ 501(c)(7)); "[f]raternal beneficiary societies, orders, or associations . . ." (§ 501(c)(8)); "[c]emetery companies . . ." (\$501(c)(13)); "[a] post or organization of war veterans . . " (§501(c)(19)).

14. I.R.C. $\S 11$ imposes a tax on the taxable income of "every corporation," without restriction to business corporations.

15. Automobile service clubs, such as the American Automobile Association and its local affiliates, are one of the rare classes of nonprofits that have clearly been ruled not to qualify for exemption on the ground that their activities do not fall within the scope of I.R.C. $\S 501$ (c). See Chattanooga Auto. Club v. Commissioner, 182 F.2d 551 (6th Cir. 1950); G.C.M. 23688, 1943 C.B. 283, as modified by Rev. Rul. 69-635, 1969-2 C.B. 126.

16. One example of such expansive reinterpretation of the exemption to accommodate new forms of nonprofit activity is provided by the nursing home industry. That industry was virtually nonexistent until the 1930s; since then, however, it has grown rapidly. Sec THE NATION'S HEALTH FACILITIES, TEN YEARS OF THE HILL-BURTON HOSPITAL AND MEDICAL FACILITIES PROGRAM, 1946-56, at 83-86 (Public Health Service Pub. No. 616, 1958). Although today the overwhelming majority of nursing homes are proprietary, roughly one quarter of non-governmental nursing homes (measured by expenditures) are nonprofit. See U.S. DEP'T OF COMMERCE, BUREAU OF THE CENSUS, 1977 CENSUS OF SERVICE INDUSTRIES: OTHER SERVICE INDUSTRIES 53-1-2,3 (SC77-A-53, 1981). Most nonprofit nursing homes receive no significant amount of philanthropic support and provide no meaningful amount of free or below-cost care. See U.S. DEP'T OF HEALTH, EDUCATION, AND WELFARE,

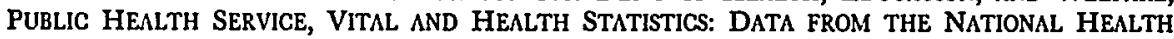
SURVEY, SERIES 18: NO. 32, CHARGES FOR CARE AND SOURCES OF PAYMENT FOR RESIDENTS IN NURSING HOMES 113 (1977) (as of 1977 less than 6.6\% of residents in nonprofit and governmental nursing homes had their care paid for primarily by private charity). Rather, like their for-profit counterparts, nonprofit nursing homes typically just sell their services to their residents at a price that covers the full cost of those services. (In other words, they are "commercial" nonprofits in the sense defined at p. 59 infra.) Nevertheless, the Internal Revenue Service has chosen to interpret the exemption to cover virtually all nonprofit nursing homes in spite of their non-philanthropic character, on the ground that they are "charitable" organizations and consequently are covered by the language of I.R.C. $\S 501$ (c)(3). See Rev. Rul. 72-124, 1972-1 C.B. 145. The policy underlying this broad reading of the term "charitable" has never been enunciated.

Nonprofit hospitals provide a similar example. Until recently, a nonprofit hospital qualified for tax exemption-as a "charitable" institution under I.R.C. \$ 501(c)(3)-only if it provided a meaningful amount of free or below-cost care to the poor. Since nonprofit hospitals typically were, in fact, philan- 
roughly congruent with the outlines of the nonprofit sector as a whole, ${ }^{17}$ offers clear evidence of the lack of, and need for, a coherent policy on which to base the exemption.

With these basic characteristics of the nonprofit corporation and its income tax exemption defined, we can now turn to a consideration of the justifications that have been, or could be, offered for the exemption.

\section{Do Nonprofits Have Taxable Income?}

It has been suggested that nonprofits are granted exemption because they have no income in the sense in which that term is used in the Internal Revenue Code.

\section{A. Can We Construct a Workable Definition of Income for Nonprofits?}

Bittker and Rahdert, for example, argue at length that any effort to use ordinary tax accounting to define taxable income for a nonprofit leads to

thropic institutions until the 1920's or 1930's, this interpretation sufficed to encompass the great majority of nonprofit institutions in the industry. Technological and financial changes in recent decades, however, have changed the character of nonprofit hospitals to the point where the typical nonprofit hospital provides no substantial amount of subsidized care, but rather offers its services only to those who can demonstrate the ability to pay for them. See Hansmann, supra note 2, at 866-68. Rather than continuing to apply its long-standing criterion for the exemption, and thus deny the exemption to most hospitals, the Service chose to reinterpret the term "charitable" so that subsidized care would no longer be required. Rev. Rul. 69-545, 1969-2 C.B. 117. A coherent rationale for this redefinition of the exemption was never expressed by the Service. This imaginative broadening of the statutory category of "charitable" organizations was challenged, but was sustained by the Court of Appeal, in an opinion which sheds no light of its own on the policy issues involved. Eastern Ky. Welfare Rights Organization v. Simon, 506 F.2d 1278, 1288-89 (D.C. Cir. 1974), rev'd on other grounds, 426 U.S. 26 (1976).

The performing arts are yet another case in point. Early in the century, when the contours of the exemption from the corporate tax were first established, the performing arts were dominated by proprietary firms; the great number of nonprofit firms currently to be found in this industry is largely a product of recent decades. See Hansmann, Nonprofit Enterprise in the Performing Arts, 12 BELL J. ECON. 341 (1981). The performing arts are not covered clearly-or, one might reasonably conclude, even remotely-by any of the various exempt purposes set forth in I.R.G. $\S 501$ (c). Nevertheless, rather than deny exemption to such a large and growing class of nonprofits, the Service chose to engage in another act of imaginative reinterpretation, ruling that the performing arts come within the category of "educational" institutions covered by $\S 501$ (c)(3). See Treas. Reg. $\S 1.501$ (c)(3)-1(d)(3)(ii) (example (4) (1959)) (symphony orchestras "and other similar organizations"); Rev. Rul. 64-175, 1964-1 C.B. 185 (repertory theater). (Although nonprofit performing arts firms typically rely heavily upon philanthropic financing, the Service was evidently unwilling to extend its definition of the statutory category of "charitable" institutions to encompass them, as it did in the case of nursing homes and non-philanthropic hospitals. Perhaps this was because performing arts organizations so conspicuously fail to provide services either to the poor or to the public at large-the traditional legal criteria for determining what is encompassed by the term "charity," see G. G. BOGERT \& G. T. BOGERT, THE LAW OF TRUSTS AND TRUSTEES $\$ 369$ (2d ed. 1964)-serving, rather, primarily to provide entertainment for the well-to-do).

17. As the examples in the preceding footnote suggest, it appears that the exemption has been kept largely coextensive with the scope of the nonprofit sector primarily through the continual redefinition of the exemption to accommodate it to changes in the activities undertaken by nonprofits, and not because nonprofits tend to develop or survive only in industries in which the exemption has already been clearly established. See Hansmann, supra note 2 , at 882 . 
absurdities. ${ }^{18}$ Are contributions made to a charity to be included in figuring the organization's gross income? Or should they, perhaps, be treated as ordinary gifts and therefore be excluded from gross income for tax purposes? Should expenditures made by a charity to assist an impoverished individual be deductible as ordinary business expenses? Or are they more correctly treated as non-deductible gifts? There are no satisfactory answers to these and other basic questions, Bittker and Rahdert suggest; the concept of taxable income developed for business organizations simply cannot be carried over to nonprofits in any meaningful way. ${ }^{19}$

But Bittker and Rahdert overstate the difficulties. To begin with, many nonprofits receive little or no income from donations, but rather derive all or nearly all of their income from sales of goods or services that they produce. These organizations-which can conveniently be referred to as "commercial" nonprofits ${ }^{20}$-in fact account for a large portion of the nonprofit sector. ${ }^{21}$ They include, for example, Consumers Union (the publisher of Consumer Reports magazine), automobile clubs affiliated with the American Automobile Association, the Educational Testing Service, many private schools, and probably most hospitals, nonprofit nursing homes, and day care centers. For such organizations it would be perfectly easy and natural to carry over the tax accounting that is applied to business firms, taking receipts from sales as the measure of gross income and permitting the usual deductions for expenses incurred in producing the goods or services sold. The resulting net earnings figure could be taxed just as in the case of a business firm. Since nonprofits cannot distribute their net earnings, such a tax would effectively be levied on the sum of (1) earnings saved for expenditure in future years, and (2) net capital investment (i.e., the excess of expenditures on capital equipment over depreciation allowances ${ }^{22}$ ). Following conventional usage, this sum will occasion-

18. Bittker \& Rahdert, supra note 1, at 307-14.

19. Rather surprisingly, the Internal Revenue Service seems never to have addressed, in general terms, the problem of defining taxable income for a non-exempt nonprofit. One reason for this is apparently that, given the broad view that the Service has taken of the exemption, see p. 58 supra, it has never been forced to give the issue much consideration. Conversely, one suspects that the Service has taken a broad view of the exemption in part, at least, to avoid having to confront the problem of defining taxable income for nonprofits.

In the few cases in which the Code itself defines taxable income for a limited class of nonprofits for some special reason, as in the case of certain political organizations under I.R.C. $\$ \S 527 \& 4911$, the definition is ad hoc and is apparently based on no coherent principles of taxation.

20. The terminology derives from the classification introduced in Hansmann, supra note 2, at 840-41.

21. In 1976 , only $15 \%$ of the total revenues of nonprofit organizations came from contributions, gifts, and grants; $70 \%$ came from sales and receipts, and $15 \%$ came from dues and assessments. Weisbrod, Economics of Institutional Choice, forthcoming in THE INTERACTION OF THE PUBLIC, PRIVATE, AND NON-PROFIT SECTORS (M. White ed. 1981).

22. It is important to keep in mind here that, since we have, for corporations just as for individuals, an accretion-type rather than a consumption-type income tax (the difference between which is essentially that the former taxes interest while the latter does not), see Andrews, $A$ Consumption- 
ally be referred to below simply as "retained earnings."

At best, then, arguments concerning the impossibility of applying ordinary tax accounting to nonprofits apply only to nonprofits that receive substantial income in the form of donations-a class of nonprofits that will be referred to here, for convenience, as "donative" nonprofits" 24 and not to commercial nonprofits. In this connection we should note that it is, in fact, not donative but commercial nonprofits that have created the greatest confusion in applying the exemption. ${ }^{25}$ For example, there has

Type or Cash Flow Personal Income Tax, 87 HARv. L. REv. 1113 (1974), expenditures for capital equipment are not immediately deductible in determining taxable income; rather, the firm can deduct in a given year only the amount by which the value of its capital assets has depreciated in that year. Thus, a firm that devotes $100 \%$ of its net earnings in a given year to the purchase of new capital equipment will still be liable for taxes so long as the amount spent on the new equipment exceeds the total depreciation for that year on the firm's existing capital equipment.

23. Although there is debate on the matter, it has been claimed that the depreciation deductions permitted under the federal corporate income tax are excessive (that is, in excess of actual decline in value), at least for certain classes of capital expenditures, and particularly after the recent liberalization of these deductions. See H.R. REP. NO. 215, 97th Cong., 1st Sess. 206 (1981) (stating that one purpose of the Economic Recovery Tax Act of 1981 is to establish depreciation allowances in excess of actual decline in value, in order to stimulate investment). To the extent that this is the case, there is a corresponding reduction in the effective rate of tax on net capital investment by firms subject to income tax-and the importance of the exemption is decreased proportionately. At the extreme, there would be a zero rate of tax on retained earnings devoted to capital investment if $100 \%$ of the cost of a capital expenditure could be deducted in the year in which the expenditure was made. Under such a regime, the rationale offered for the exemption in Section VI below would lose some of its force. See note 78 infra.

24. See note 20 supra.

25. Bittker \& Rahdert, supra note 1, speak of nonprofits in terms of two broad categories: "public service" organizations and "mutual benefit" organizations. The authors offer no definition for either of these categories; rather, they simply provide representative lists of organizations that they feel typify the two categories. Thus, they state that the principal types of organizations in the public service category are charitable organizations, educational institutions, scientific organizations, social welfare organizations, churches and other religious organizations, and political parties, while they state that "the most important" examples of mutual benefit nonprofits are social clubs, consumer cooperatives and similar organizations, labor unions, and trade associations. Id. at 305-06. From these examples, and from their discussion of the issues presented by these two categories, it seems clear that when Bittker and Rahdert speak of "public service" nonprofits they are thinking of donative nonprofits, and that when they speak of "mutual benefit" nonprofits they have in mind nonprofits that not only serve primarily to provide services directly to the individuals who patronize them but are, further, organized as membership organizations directly controlled by the patrons they serve (a class of organizations that is elsewhere labeled "commercial mutual" nonprofits, see Section XI, pp. 43-96 infra).

The discussion offered by Bittker and Rahdert generally proceeds as if there were no other important categories of nonprofits. Yet their categorization, and their discussion in general, omits the largest and most troublesome class of nonprofits-namely ordinary commercial nonprofits (or, more precisely, "commercial entrepreneurial" nonprofits-that is, commercial nonprofits that are not organized as membership organizations, see p. 93 infra.) It is striking, for example, that nowhere in their long article do Bittker and Rahdert discuss the exemption as it applies to nonprofit hospitals, though hospitals alone seem to account for roughly half of the GNP generated by the nonprofit sector, see Hansmann, supra note 2 , at $835 \mathrm{n.1}$, and though, as noted in the text immediately following, the application of the exemption to hospitals has recently been the focus of considerable controversy.

Bittker and Rahdert's division of nonprofits into "public service" and "mutual benefit" organizations parallels the categorization of nonprofits in the recently enacted California Nonprofit Corporation Law, GAL. CORP. CODE $\$ 5,000-10,846$ (West Supp. 1981), which divides nonprofit corporations into "nonprofit public benefit corporations" and "nonprofit mutual benefit corporations," and applies different standards of conduct to the two types. The categorization established by the California act is 
been considerable controversy over the IRS's 1969 decision to alter its policy and explicitly extend the exemption not only to hospitals that are donative, as has always been done, but also to hospitals that are operated strictly as commercial nonprofits. ${ }^{26}$

Yet even for donative nonprofits there is a natural correlate to the concept of taxable income developed for business entities. Consider, for example, a donative organization like the American Red Cross. If an individual makes a contribution to the Red Cross, it is presumably with the intention that the money will be used to provide food, housing, and medical treatment for disaster victims. In other words, the contributor is in effect buying disaster relief. And the Red Cross is, in a sense, in the business of producing and selling that disaster relief. ${ }^{27}$ The transaction differs from an ordinary sale of goods or services, in essence, only in that the individual who purchases the goods and services involved is different from the individuals to whom they are delivered.

It follows that we can view the contributions received by the Red Cross and other such donative organizations as sales receipts, and hence-if such organizations were to be subjected to income taxation-as funds that are appropriately includable in gross income. The cost of the services, such as disaster relief, rendered by donative nonprofits would then be deductible, analogously to ordinary business expenses. The result is that donative nonprofits would be taxed annually on the amount, if any, by which their total receipts, from contributions as well as from other sources (such as investment income and amounts received from ordinary sales), exceed their total expenditures on the services to which they are dedicated. As with commercial nonprofits, the tax would therefore effectively be levied on retained earnings. ${ }^{28}$

There need be nothing troubling about such a definition of income. Suppose that you pay Tiffany to ship to a friend a wedding gift that you select from Tiffany's catalogue. The structure of the transaction is much the same as if you give to the Red Cross money to spend on food for a

discussed and criticized at length in Hansmann, supra note 12, at 535-37.

26. See note 16 supra. Nursing homes, also discussed supra note 16, provide another conspicuous example. See also the cases discussed at p. 90 infra.

27. See Hansmann, supra note 2 , at $846-48,872-73$.

28. After exploring at length the absurdities of other, less natural definitions of taxable income for donative nonprofits, Bittker \& Rahdert, supra note 1, briefly note the possibility of adopting the definition suggested here and summarily dismiss it, saying only that "[s]ince these accumulations and capital outlays are irrevocably dedicated to the institution's nonprofit objectives. . . we do not regard this alternative mode of computing a nonprofit organization's income as very appealing; nor can we see that it has any economic or social advantages over a regime of complete exemption." Id. at 312.

Rather surprisingly, Bittker and Rahdert proceed to argue elsewhere in their article that business leagues-which often take the form of donative nonprofits-should be taxed, and suggest that " $[\mathrm{t}$ ) would be no great difficulty in applying familiar principles of income computation to their activities ...." Id. at 357. 
flood victim; in each case you are paying an organization to render services to a third party. Yet few would argue seriously that the amount you give Tiffany is not appropriately includable in Tiffany's income, or that the cost of sending the gift should not be considered a deductible expense for them. ${ }^{29}$

\section{B. Will There Be Any Long-Run Tax Liability?}

Thus, it seems that without much difficulty we can extend to nonprofits the general principles of tax accounting commonly applied to profit-seeking firms. But will such accounting actually lead to any tax revenue ${ }^{30}$ An argument against taxing the income of nonprofits that one sometimes hears is that, in the long run, nonprofits will necessarily have no net profits, since, by virtue of the nondistribution constraint, they must ultimately spend all of their income on the purposes for which they were formed, and hence their total expenses must ultimately equal their total income.

The strength of this argument depends on several factors, including the detailed accounting conventions employed. In particular, in order for the cumulative net long-run tax liability of a nonprofit to be zero, it must be the case that (1) all expenditures made by the nonprofit, including distributions upon dissolution, are considered deductible expenses, (2) losses in any year can be carried back to cover gains in any previous year, (3) the nonprofit has relatively free access to borrowed funds, and in particular

29. This brief discussion obviously leaves unresolved a number of accounting issues in the definition of taxable income for donative nonprofits. For example, consider the case of a nonprofit that receives in a given year a large gift that is used for the acquisition of capital equipment. If the total amount of the gift were to be included in the organization's gross income for the year of receipt, there might be large apparent profits for that year, and hence a large tax liability. Yet this apparent profit is of course somewhat illusory; it will be balanced in future years by the losses generated by the depreciation of the capital equipment. This problem might be dealt with by making generous provision for income averaging of some form, such as by permitting losses to be carried back for more than the three years currently provided for in I.R.C. $\S 172(\mathrm{~b})(1)(\mathrm{A})$. Alternatively, the amount of such a gift that is used for the acquisition of capital equipment could simply be excluded from gross income, and the organization given a zero basis for the equipment thus purchased (so that no depreciation could be taken in future years), as is currently done with nonshareholder contributions to capital for business corporations under I.R.C. § 362(c).

These and other questions of detail in the definition of taxable income for donative nonprofits will not be explored here in depth. The objective at this point is only to demonstrate that it is by no means impossible to construct a definition of taxable income for nonprofits of all types that is consistent and that proceeds along lines analogous to those employed in defining taxable income for business corporations. It will, in any case, be suggested below that there is a justification for continuing the current policy of exempting nearly all donative nonprofits, and thus there is no need to go into detail concerning the proper tax accounting for such organizations.

30. There appear to be no available estimates of the additional tax revenues that might be collected from nonprofit organizations if the income tax exemption for nonprofits were eliminated. In particular, such a figure has not been included in the "tax expenditure" budgets that have been calculated by the federal government, see STAFF OF JOINT COMM. ON TAXATION, ESTIMATES OF FED. ERAL TAX EXPENDITURES FOR FISCAL YEARS 1980-1985 (1980), perhaps because of confusion as to (1) whether in fact the exemption amounts to a subsidy, and (2) the related issue of how a nonprofit's tax liability would be computed in the absence of the exemption. 
can, without affecting its ability to borrow for other purposes, borrow funds in any year at least equal to that year's tax liability plus interest due on loans taken out in previous years to cover tax liabilities, and (4) refunds from the Treasury of taxes that were overpaid in previous years are accompanied by payment of interest by the Treasury at a rate equal to the rate that the nonprofit must pay on funds that it borrows. ${ }^{31}$ These four conditions, however, do not all hold. At present, losses can be carried back only three years. ${ }^{32}$ Further, the Treasury does not pay interest when refunding overpayments from previous years. ${ }^{33}$ And, perhaps most importantly, nonprofits do not have unrestricted access to borrowed capital-the consequences of which are explored at length below. ${ }^{34}$

\section{Is the Corporate Tax Just a Tax on Capitalists?}

At this point a further objection might be-and sometimes has been ${ }^{35}$-raised. The corporate income tax as applied to business corporations can be viewed as, in effect, a tax on the returns to investors of equity capital, and there is, by definition, no equity capital invested in nonprofit

31. To illustrate, consider a nonprofit that, in the absence of taxes, would be in existence for just three years, and would have the following receipts and expenses. Year 1: the organization receives a $\$ 100$ donation, and spends it all on nondepreciating capital equipment. Year 2: the organization produces and sells services that bring in receipts that exceed operating expenses by $\$ 25$, and uses this $\$ 25$ to buy additional capital equipment. Year 3: the organization again earns $\$ 25$ above operating expenses, as in the previous year; sells its capital equipment at the end of the year for \$125; dissolves; and gives away its $\mathbf{\$ 1 5 0}$ in net assets (perhaps to another organization performing similar services).

Now suppose that this same organization were subject to corporate income taxation, using a definition of taxable income such as that suggested at pp. 59-61 supra, under which all income, including donations as well as sales receipts, is included in calculating gross income. If the four conditions stated in the text were satisfied, then the organization could behave just as it would in the absence of taxation, with the simple addition that in each of the first two years it would borrow the amount necessary to cover its tax liability for that year plus any interest on previous borrowing, and in the third year it would repay the loans plus current interest with the tax refund that it would receive by carrying its third year loss back to cover the earlier year's profits.

For example, if the tax rate were $50 \%$, and if the organization could borrow at $10 \%$ interest, in Year 1 the organization would have a tax liability of $\$ 50$ (based on the $\$ 100$ gift), and would borrow the amount needed to pay this. In Year 2, the firm would have a tax liablity of $\$ 10$ (based on gross income of $\$ 25$ less $\$ 5$ in interest payments), and borrow $\$ 15$ to cover this amount plus the $\$ 5$ interest on the previous year's loan. In Year 3, the organization would have a loss, for tax purposes, of $\$ 131.50$ ( $\$ 25$ gross income-the sale of the capital equipment is a wash since the sale price equals the basis-minus $\$ 6.50$ in interest payments on the $\$ 65$ in outstanding loans and minus $\$ 150$ for the terminating distribution). The organization would carry back $\$ 120$ of this loss to cover the profits reported in earlier years, and as a result would receive from the Treasury the $\$ 60$ in previous tax payments plus $\$ 11.50$ in interest on those overpayments (at $10 \%$ ), or a total of $\$ 71.50$. The interest payment from the Treasury would just be offset by the remaining $\$ 11.50$ in losses for the current year, and thus would generate no further tax liability. The firm would then use the $\$ 71.50$ refund from the Treasury to pay off the $\$ 65$ principle plus $\$ 6.50$ interest on its outstanding loans, thus ending up with a clean slate with respect to both borrowing and taxes.

32. I.R.C. $\S 172(\mathrm{~b})(1)(\mathrm{A})$.

33. Id. $\S 6611(\mathrm{f})(1)$.

34. See pp. 71-74 infra.

35. See Bittker \& Rahdert, supra note 1, at 345. 
firms. Thus, it might be argued, the net earnings of nonprofits should not be equated, for tax purposes, with the net earnings of business corporations, since only the latter ultimately accrue to the benefit of private investors. In other words, the tax "base" for the corporate income tax simply does not extend to nonprofits.

This argument proves too much, however, for it suggests that all nonprofit corporations should be exempt, whereas exemption has in fact always been available only to certain categories of them, ${ }^{36}$ and so far even the strongest supporters of the exemption have not suggested that it be extended to all organizations that are legitimately formed as nonprofit corporations. ${ }^{37}$ Besides, is it so clear that there is no investor of equity capital in a nonprofit? Can we not view the nonprofit corporation itself as the ultimate owner of its capital, and hence treat it as the taxpayer? After all, the income tax even as applied to business corporations has commonly been rationalized on the basis that the corporation itself has taxable capacity apart from its investors-that it is conceptually a separate taxable entity. ${ }^{38}$ Or might we not view the patrons of a nonprofit, or perhaps the recipients of its services (if they differ from its patrons), as the beneficial owners of its invested capital?

Obviously, simple analogies and metaphors-which are too often the primary analytic tools of lawyers, including tax lawyers-will not yield a satisfying answer as to whether or not we should tax the net earnings of nonprofit organizations. Rather, we must examine and judge the actual consequences of imposing such a tax. That is, we must consider what the world would look like both with and without such a tax, and then decide which world we like better. In undertaking such an analysis of economic policy it is, as usual, convenient to divide the problem into two aspects: distribution and efficiency. The following discussion considers these aspects in turn.

\section{Distributional Considerations}

It has been argued that an income tax levied on nonprofits would be inappropriate because it would not be related to the "ability to pay" of those on whom the burden of the tax would fall..$^{39}$ For example, a tax on a donative organization like the Salvation Army would, it is said, be borne by the poor to whom that organization renders services, and such a tax

36. Moreover, we now tax the unrelated business income even of exempt nonprofits, see p. 55 supra-though Bittker \& Rahdert, supra note 1, at 316-26, are consistent in suggesting a reversal of this policy.

37. Including Bittker and Rahdert. See, e.g., note 28 supra.

38. See C. MCCLURE, supra note 10, at 28-38.

39. See, e.g., Bittker \& Rahdert, supra note 1, at 314-16. 
would therefore be unacceptably regressive. There are, however, several difficulties with such reasoning.

To begin with, the corporate income tax even as applied to business corporations is seldom justified on the basis of the "ability to pay" of the individuals who ultimately bear its burden. As already noted, supporters of that tax frequently seem to view corporations as independent taxable entities with taxpaying capacity of their own, quite apart from their shareholders, workers, or consumers. ${ }^{40}$ Indeed, there remains considerable uncertainty as to the actual incidence of the corporate tax. ${ }^{41}$ In any case, since the structure of the corporate tax makes the business corporation a tax shelter for high-bracket investors, ${ }^{42}$ there is no reason to believe that the tax is particularly progressive.

Moreover, it is not obvious that the ultimate incidence of an income tax levied on nonprofits would be especially regressive. Where donative nonprofits are involved, we should probably see the donors as sharing in the burden along with the beneficiaries, ${ }^{43}$ and the donors are likely to be, on average, rather prosperous. Also, as already noted, donative nonprofits often are not redistributive, like the Salvation Army, but rather provide services that benefit primarily the (generally well-heeled) class of people comprising the organization's donors. This is generally true, for example, of art museums, performing arts groups, churches, and, to the extent that they are donative at all, educational and health care institutions. For such organizations the burden of taxation, whether it falls on the donors or the beneficiaries, is unlikely to be unacceptably regressive. We should remember, too, that a large proportion of nonprofits are essentially commercial rather than donative organizations (in the sense defined above), and that the services of these organizations seem to be consumed disproportionately by the relatively affluent. In general, when considering tax incidence or any other aspect of policy affecting nonprofits, we should avoid the common tendency to think primarily in terms of traditional charities such as the Salvation Army or the Red Cross. We should keep in mind, rather, that the great bulk of the nonprofit sector is comprised of service institu-

40. See p. 64 supra.

41. See, e.g., Harberger, The Incidence of the Corporation Income Tax, 70 J. POL. ECON. 215

(1962); Stiglitz, supra note 10.

42. See Warren, The Relation and Integration of Individual and Corporate Income Taxes, 94 HARV. L. REV. 717, 723 (1981).

43. In keeping with the discussion in Section II, we might view the incidence of a tax on a donative nonprofit such as the Salvation Army in much the same terms as we would a sales tax on a wedding gift that you buy at Tiffany for a friend. Depending on the elasticity of your demand for such a gift with respect to price, you may well end up spending a larger gross (i.e., after-tax) amount on the gift with the tax than without it. Moreover, even if the gross amount that you spend remains constant or declines upon imposition of the tax, your welfare will decline because the quality of the gift that you can buy with a given dollar expenditure will decline (and we must keep in mind that the donor, as well as the donee, presumably derives utility from the gift). 
tions such as private colleges and hospitals ${ }^{44}$ and that these latter institutions-which, altogether, probably serve the prosperous more than they do the poor-would be the nonprofits most affected by any change of policy.

Finally, the exemption benefits only those nonprofits that have retained earnings, and the extent of this benefit is directly proportional to the amount of income accumulated. Yet most highly redistributive charities do not retain earnings in substantial amount, but rather pass their (largely donative) income directly through to their beneficiaries. Nonprofits that retain a substantial portion of their income from year to year-in the form of capital expenditures or endowment funds-are generally organizations, such as private schools, colleges, and hospitals, that disproportionately serve the well-to-do.

In short, it seems that distributional considerations-or "ability to pay"-are not dispositive in judging the desirability of a tax on the net income of nonprofits. Consequently, our pursuit of a rationale for the exemption must continue. We therefore turn to considerations of economic efficiency.

\section{Subsidization of Services}

A rather common view of the exemption is that it is a means of subsidizing particular services-such as health care, education, research, and aid to the poor-that nonprofit organizations often provide. For example, those who suggest that nonprofits should be granted the exemption because they provide services that otherwise would have to be provided by the government presumably subscribe to such a view..$^{45}$ An obvious advantage of this rationale is that it provides some justification for the existing practice of extending the exemption, not to all nonprofit organizations, but rather only to those that serve purposes specifically listed in the tax code.

If this is in fact the theory on which the exemption is based, then in order to determine whether the exemption is good policy, one would want to examine the reasons why each activity qualifying for the exemption ${ }^{46}$ would otherwise be undersupplied by the private market, and therefore require a government subsidy. Such justification might be sought, for example, in the existence of uncompensated benefits ("beneficial externalities") that the activity brings to the society at large. Rather than undertake such an inquiry here, however, we shall focus on two more general and fundamental difficulties that confront such a subsidy theory: First, why is the exemption extended only to nonprofit, and not also to for-

\footnotetext{
44. See Hansmann, supra note 2, at 835 n.1.

45. E.g., Stone, supra note 5, at 45.

46. See note 13 supra.
} 
profit, providers of the services? And second, if the intention is to subsidize the provision of services, does it make any sense to provide a subsidy that is tied directly to the size of an organization's retained earnings?

\section{A. Why Not Exempt For-Profit Firms Also?}

The exemption for nonprofit firms does not make much sense as a subsidy for provision of services unless we can understand why the exemption is not granted as well to for-profit providers of the same services. If, for example, private nonprofit hospitals and secondary schools are granted exemption in order to subsidize the provision of hospital care and secondary education, why are not for-profit hospitals and secondary schools also exempted from income taxation?

There are, in fact, several possible arguments for confining subsidies for certain services just to nonprofit providers. Standing on their own, however, none of these arguments is terribly compelling.

\section{Subsidy Incidence}

To begin with, the nondistribution constraint that characterizes nonprofits provides some assurance that a subsidy to a nonprofit will redound to the benefit of the consumers of the organization's services in the form of lower prices or higher quality. There might be concern that the benefit of a tax exemption for a profit-seeking firm would simply go to the owners of the business in the form of higher profits.

Yet in a reasonably competitive market consumers would receive most or all of the benefit of a subsidy even to for-profit firms. Consequently, confining the subsidy to nonprofits is necessary only if there is market failure of some sort preventing effective competition among profit-seeking firms. Even then, the precise incidence of the subsidy to for-profit firms as between consumers on the one hand and owners on the other would depend on the particular form that market failure takes. Even a profit-maximizing monopolist, for example, will have an incentive to pass on to consumers some of the benefit of a cost subsidy. ${ }^{47}$

The services provided by nonprofit firms are, in fact, typically such that market failure is to be expected among profit-seeking producers of those services. The particular form of market failure involved, which will be referred to here as "contract failure,"48 and which is described in more detail below, ${ }^{49}$ derives from the inability of some or most consumers to

47. When a monopolist's marginal cost of production is reduced (as it would be by a subsidy), his profit-maximizing level of output increases, and the profit-maximizing price for his product decreases.

48. The term derives from Hansmann, supra note 2 , at 845 .

49. Pp. 69-70 infra. 
make accurate judgments concerning the quality, quantity, or price of services provided by alternative producers. It is possible that the existence of contract failure would provide an opportunity for profit-seeking producers to divert to themselves some portion of the benefit of a tax subsidy. ${ }^{50}$ If so, there may be some justification for confining tax subsidies to nonprofit firms, at least for those services that are subject to contract failure. This is, however, a rather attenuated argument.

\section{Production of Public Goods}

An alternative reason for confining tax subsidies just to the nonprofit firms within given industries could be that the nonprofits tend to produce a different product mix than do the for-profit firms. In particular, many nonprofits serve an important role in producing public goods (in the economist's sense of that term), ${ }^{\text {st }}$ which would be undersupplied without subsidies. For example, it seems that nonprofit educational institutions are more likely to produce research, and nonprofit day care centers are more likely to provide free service for the poor, than are their proprietary counterparts.

This is surely a plausible rationale for subsidizing nonprofit producers of certain services, though it is doubtful whether this rationale can be extended to the entire class of nonprofits to which the exemption has been granted. For example, as already noted, in recent years the exemption has been explicitly interpreted to encompass virtually all nonprofit hospitals, whether or not they provide free care for indigents or engage in other activities that might be thought to involve benefits to society at large. ${ }^{52} \mathrm{~A}$ similar policy also seems to have been adopted with respect to nursing homes. ${ }^{53}$ And private educational institutions, including primary schools, secondary schools, and colleges that have no graduate programs and produce insignificant amounts of research, have also long been routinely exempted. ${ }^{54}$ Since such essentially private-service institutions constitute a large fraction, in dollar terms, of the entire nonprofit sector, ${ }^{55}$ they represent no small exception to the public goods theory of tax subsidization.

50. Precisely how much, if any, of a tax subsidy could be captured by the owners of for-profit firms in such circumstances is, however, quite uncertain. At present we know rather little about the dynamics of competition in markets populated by both nonprofit and for-profit firms. See Hansmann, supra note 2 , at $899-901$.

51. See B. WEISBROD, THE VOLUNTARY NONPROFIT SECTOR (1977); Hansmann, supra note 2, at 848-54.

52. See note 16 supra.

53. See id.

54. See Reg. § 1.501(c)(3)-1(d)(3)(ii) (example (1)).

55. See note 21 supra; Hansmann, supra note 2 , at 835 n.1. 


\section{Quality of Service}

It has already been remarked that the services provided by nonprofits are commonly characterized by a particular type of market failure termed "contract failure." The problems of contract failure arguably provide the basis for yet another rationale for giving selective subsidies to nonprofit providers of many services. To understand this argument, and to understand as well the alternative analysis of the exemption that will be offered later in this Article, a closer description of contract failure-which has been analyzed in far greater detail elsewhere ${ }^{56}$-is in order.

Contract failure arises when, owing to the nature of the service itself or to the circumstances under which it is consumed, the purchasers of the service-whether we style them donors or consumers-are likely to have difficulty in (1) comparing the quality of performance offered by competing providers before a purchase is made, or (2) determining, after a purchase is made, whether the service was actually performed as promised. As a result of such conditions, ordinary market competition may be insufficient to police the performance of for-profit firms, thus leaving them free to charge excessive prices for inferior service. In such circumstances consumers often turn to nonprofit providers, which, owing to the nondistribution constraint, have less opportunity and incentive to exploit consumers than do for-profit firms, and thus serve as fiduciaries of a sort for their consumers.

Consider, for example, a typical donative nonprofit such as the Red Cross. As noted earlier, that organization is essentially in the business of "selling" disaster relief services to its contributors, for delivery to third parties. A for-profit firm might conceivably produce the same services-offering, say, to provide some given amount of food, medical care, or alternative housing to disaster relief victims-in return for payment of a specified sum. The difficulty is that, because the services are to be provided to third parties with whom the purchaser has no contract, and because the services involved are often of an indivisible character that makes it difficult to specify in advance precisely what the firm is to provide in return for each individual purchaser's payment, individuals patronizing such a for-profit version of the Red Cross would have considerable difficulty in drawing up a meaningful contract specifying the services to be performed, and in judging subsequently whether the firm had in fact performed the services as promised. With a nonprofit producer, in contrast, the patron has some assurance, by virtue of the nondistribution constraint,

56. Hansmann, supra note 2. See also Nelson \& Krashinsky, Two Major Issues of Public Policy: Public Subsidy and Organization of Supply, in PUBLIC POLICY FOR DAY CARE OF YOUNG CHILDREN 47 (D. Young \& R. Nelson eds. 1973). 
that all of the funds he turns over to the firm will in fact be used to produce the services that the firm holds itself out as providing, and thus he need not try to draw up and enforce a detailed contract with the firm.

Such problems of contract failure are most conspicuous in the case of services provided by donative nonprofits, which commonly involve delivery of the service to third parties, and in the provision of public goods with their attendant problems of indivisibility. Contract failure is presumably less of a problem with services provided by commercial nonprofits, which are by definition private goods delivered directly to the individuals who pay for them. Nonetheless, it appears that commercial nonprofits, too, often have arisen in response to problems of contract failure. Complex personal services such as day care and residential nursing care, for example, may be quite difficult for some consumers to evaluate with confidence, thus leading those consumers to seek out nonprofit providers as a form of protection against exploitation.

In short, under circumstances of substantial contract failure, nonprofit firms may serve consumers more efficiently ${ }^{57}$ than for-profit firms. Perhaps, then, tax exemption can be justified as a means of encouraging the development of nonprofit firms in those industries in which, owing to the existence of contract failure, they are likely to have this efficiency advantage.

To be sure, it is not clear that this theory helps to justify the exemption in such important fields as hospital care, where the contract failure theory of nonprofits seems weakest. ${ }^{58}$ But this may simply be a problem of an uncritical overextension of the exemption. A more fundamental problem with such a theory, however, is that it is not obvious why a subsidy is needed to encourage nonprofits even where their development seems appropriate as a response to contract failure. Why can consumers not be trusted to select nonprofit rather than proprietary producers on their own in those situations in which nonprofits are to be expected to offer more reliable service? And, if there are cases in which consumers cannot in fact

57. To be more precise, the potential advantages, in terms of economic efficiency, offered by nonprofit producers in situations of contract failure derive from such things as (1) a reduction in the efforts that consumers feel impelled to make to police the provider of a service when the provider is nonprofit rather than for-profit, (2) a reduction in the disparity between cost and price occasioned by the elimination of the excessive profits that for-profit producers might be able to secure, and (3) prevention of the type of degeneration that threatens "lemons"-type markets, see Akerlof, The Market for "Lemons": Quality, Uncertainty and the Market Mechanism, 84 Q.J. ECON. 488 (1970).

There are, on the other hand, certain inefficiencies that also seem characteristic of the nonprofil form. Most notable among these is the reduced effort to minimize costs that seems to accompany the elimination of ownership rights in the organization. Nonprofit firms are to be preferred to for-profit firms on efficiency grounds only when such inefficiencies are more than counter-balanced by efficiency gains such as those described above. See Hansmann, supra note 2, at 844-45, 877-79.

58. See Clark, Does the Nonprofit Form Fit the Hospital Industry? 93 HARV. L. REV. 1416 (1980); Hansmann, supra note 2, at 866-68. 
be trusted to make such a decision wisely, is not a tax subsidy a remarkably indirect response to the problem? Should not proprietary producers be outlawed entirely-or at least put under severe regulatory restraint-where they are obviously unsuitable but are likely to attract consumers nonetheless?

\section{B. Does a Subsidy Tied to Net Income Make Sense?}

Even if one were to conclude, on the basis of one or more of the three theories just surveyed, that a subsidy confined to nonprofit providers of certain services is appropriate, it does not necessarily follow that subsidizing these services through the particular device of exemption from income taxation makes much sense. If we adopt the natural definition of taxable income suggested earlier, ${ }^{60}$ the amount of the subsidy that results from exemption will be directly proportional to retained earnings. But there is no reason to expect a positive correlation between the amount of a nonprofit's retained earnings and the factors just described that might justify a subsidy - such as the degree of contract failure that characterizes the services that the nonprofit produces, or the extent to which the nonprofit produces public as opposed to private goods.

In fact, there is some reason to connect the amount of subsidy that a nonprofit receives to its retained earnings. But before advancing that argument, let us briefly consider another, rather different rationale for the exemption-namely that it is required in order to avoid defeating the policies that lie behind the charitable deduction.

\section{Consistency with the Charitable Deduction}

If an individual makes a contribution to any of a large class of nonprofits-a class that constitutes a subset, though a substantial subset, of those nonprofits that qualify for exemption from the federal income tax-that contribution can be deducted from the individual's income when he calculates his personal federal income tax..$^{61}$ This "charitable deduction" can be justifed reasonably convincingly on efficiency grounds as a means of encouraging individuals to contribute to the production of certain services, commonly provided by nonprofits, that are otherwise likely to be underproduced-including, in particular, public goods. ${ }^{62}$ If, for this or for other reasons, the charitable deduction is taken to be good policy, then it might

59. These issues are discussed at considerably greater length in Hansmann, supra note 12, at 519-27.

60. Pp. 59-61 supra.

61. I.R.C. $\S 170$.

62. See p. 68 supra. 
appear that the exemption can be justified on the ground that taxing the income of the nonprofits that receive deductible contributions would be taking away with one hand what has been given with the other.

This conclusion does not necessarily follow, however. In the first place, the exemption has not been confined just to those organizations that qualify for deductible contributions. ${ }^{63}$ More importantly, denial of exemption would probably have little effect on many or most donative nonprofits. Only those organizations that do not regularly spend their income (including donations they receive) currently, but rather accumulate from year to year, would face substantial income tax liabilities. Thus here, as in the preceding discussion of the exemption as a subsidy in its own right, the question comes down to determining whether it makes sense to give special encouragement or discouragement to nonprofits that accumulate income from one year to the next. As the following discussion suggests, there may in fact be good reason to give such special attention to accumulation.

\section{Compensation for Capital Constraints}

There is an efficiency rationale for the exemption that is more appealing than those discussed above, although it seems never to have been expressly offered before. That rationale is that the exemption serves to compensate for difficulties that nonprofits have in raising capital, and that such a capital subsidy can promote efficiency when employed in those industries in which nonprofit firms serve consumers better than their forprofit counterparts.

Nonprofit organizations lack access to equity capital since, by virtue of the nondistribution constraint, they cannot issue ownership shares that give their holders a simultaneous right to participate in both net earnings and control. Consequently, in raising capital, nonprofits are limited to three sources: debt, donations, and retained earnings. These three sources may, in many cases, prove inadequate to provide a nonprofit with all of the capital that it needs.

Donations are commonly an uncertain source of capital for nonprofits, and an inadequate one as well. Free-rider incentives ${ }^{64}$ presumably keep the flow of contributions to donative nonprofits-many of which provide public goods-well below the socially optimal level, ${ }^{65}$ and commercial

63. The class of organizations qualifying for the charitable deduction under I.R.C. $\S 170$ is essentially the same class that qualifies for the exemption under I.R.C. $\S 501$ (c)(3). The organizations qualifying for the exemption under the other twenty-one subsections of I.R.C. $\S 501$ (c) do not, in general, qualify for the deduction.

64. That is, incentives to refrain from contributing oneself, and simply enjoy without cost the services provided by the donations of others.

65. The charitable deduction induces a substantially more generous flow of contributions to many donative nonprofits than would otherwise be forthcoming. See Feldstein, The Income Tax and Chari- 
nonprofits, by definition, receive few gifts of any sort. Debt, too, has distinct limits as a source of capital for most nonprofits. Lenders are commonly unwilling to provide anything near $100 \%$ of the capital needs even of proprietary firms, and are evidently even more conservative in lending to nonprofit firms. ${ }^{66}$ One reason for this is that, as debt comes to account for something close to $100 \%$ of a nonprofit's capital, it becomes increasingly unlikely that the organization's assets will provide adequate security for the debt. Of course, such a lack of security need not rule out debt financing. Debt, like equity, can be used as an instrument for risky investments; one need simply run up the interest rate on loans and bonds as they come to account for a larger fraction of the organization's capital. However, the transaction costs of using debt instruments for capital financing under conditions of substantial risk are high, and presumably prohibitive beyond some point well short of $100 \%$ debt financing. ${ }^{67}$

As a consequence of these restrictions on external financing, a nonprofit organization's ability to accumulate retained earnings is of substantial importance as a means of capital expansion. The reason for this is twofold. First, accumulated earnings can be used directly to finance capital improvements. Second, the amount of debt financing that a nonprofit can

table Contributions (pts. 1 \& 2), 28 NAT'L T^X J. 81, 209 (1975). Even with this incentive, however, the private return to a donation in support of a public good is probably still well below the effective cost of the contribution to the donor.

Of course, some donative nonprofits, far from being underfunded, receive contributions in excess of the amounts they can use constructively. See note 98 infra.

66. See P. Ginsburg, Capital in Non-Profit Hospitals 26-28, 180-84 (December 1970) (unpublished doctoral dissertation available in Harvard University Library).

67. If a nonprofit's debt is so large that nearly all of its expected income beyond non-capital expenses must be devoted to interest payments, and if the organization's gross income in any given period is uncertain, there is a high probability that in any given period the organization will be unable to meet its interest obligations. When such a default occurs, the lender must decide whether to foreclose or refinance. Foreclosure is a costly procedure, whether or not the organization's assets are sufficient to cover the debt. Even if refinancing is regularly undertaken in the face of such defaults, the loans must be rewritten and the terms of the refinancing negotiated, which could be extremely awkward and costly. Indeed, the process would be so cumbersome that it would probably be impossible to undertake on a regular basis if the debt instruments involved were bonds rather than bank loans. And even with bank loans there would soon come a point, as the risk of technical default rose, at which the expected transaction costs of continual refinancing would represent an unacceptable portion of the expected return on the loans involved.

Note, too, the awkwardness of the control relationships involved with such high risk debt financing. The lender will naturally have an ongoing interest in the conduct of the organization's affairs. Yet the only way the lender can exercise some degree of control over the organization, in order to protect that interest, is to negotiate with the organization's management under the threat of withholding further credit or foreclosing in case of technical default. This is likely to be an unsatisfactory method of governing the organization's affairs from the point of view of both the lender and the borrowing organization.

Equity financing via joint stock investments has developed precisely to provide a flexible instrument for capital investment in situations involving risk. To try to use debt instruments to create the same flexibility, and to give the lender the control he needs to ensure that the borrower does not abuse that flexibility, will commonly be so cumbersome that the costs outweigh the benefits. Indeed, if one were to succeed in structuring debt investments in this way, they might well have so many of the properties of ownership shares that the borrowing organization could no longer be deemed to be nonprofit. 
obtain is proportional to some extent to the amount of revenue it can derive from retained earnings, since capital purchased with such earnings provides an extra margin of security for the debt, and since the cash flow from such earnings is evidence to lenders that interest payments on the debt can be covered. ${ }^{68}$ To be sure, retained earnings, even when added to the sources of external financing available to nonprofits, are likely to prove an inadequate source of capital where the need for expansion is strong. But at least such earnings have the advantage that they are likely to be proportional to the degree to which demand for the organization's services exceeds its ability to supply them, since excess demand will generally permit the organization to raise its prices (or attract larger donations).

A case can therefore be made against an income tax on nonprofits on the ground that such a tax would (at current corporate rates) cut retained earnings roughly in half, and hence would further cripple a group of organizations that is already capital-constrained. Or, put differently, the exemption can be understood as a subsidy to capital formation.

Of course, the mere fact that nonprofits as a class have difficulty raising adequate amounts of capital does not in itself constitute a justification for providing them with a capital subsidy. Quite the contrary: if the only thing distinguishing nonprofit from for-profit providers of a given service is that the nonprofits have difficulty raising adequate amounts of capital, then a capital subsidy to the nonprofits would simply be wasteful; the industry should be left to the for-profit firms. Indeed, presumably the reason why most sectors of our economy are dominated by for-profit firms is that they constitute, overall, the most efficient means of mobilizing productive resources-including, in particular, capital.

The problem, however, is that often nonprofits are, aside from problems of capital formation, more efficient than their for-profit counterparts in providing those services characterized by contract failure. For such services, the cost of the capital subsidy provided by corporate tax exemption may be more than compensated for by the efficiency gains deriving from the expansion of nonprofit producers that the subsidy encourages. ${ }^{69}$

68. See Ginsburg, supra note 66, at 184 .

69. There may be circumstances other than contract failure in which nonprofit firms have important efficiency advantages over for-profit firms. Such circumstances have yet to be clearly identified, however.

Some membership organizations, such as country clubs, seem to be formed on a nonprofit rather than a for-profit basis not in response to contract failure, but rather as a means of avoiding simple monopolistic exploitation. See Hansmann, supra note 2, at 892-94. In these cases, however, the nonprofit form does not seem to be the only, or even the best, way of coping with the problems of monopoly; rather, the cooperative form, which does not suffer from problems of capital formation to quite the same degree as does the nonprofit form, seems adequate, and its broader use in such circumstances could easily be facilitated without any form of special tax treatment. See id.; Hansmann, supra 
Thus, the need for capital subsidies provides some justification for exempting nonprofits from corporate income taxation in those industries in which, owing to contract failure, nonprofits have important efficiency advantages over for-profit firms. And this, it appears, is the strongest argument that can be offered for the current policy of exempting many, but not all, nonprofits from taxation.

This argument is not without difficulties. For one thing, as already noted, it is not obvious that the exemption as currently administered is confined to those industries characterized by contract failure. This objection could be met, however, by redefining the contours of the exemption as suggested below.

More importantly, an exemption from income taxation is a crude mechanism for subsidizing capital formation in the nonprofit sector. The extent to which nonprofit firms are capital constrained evidently varies considerably from one industry to another, and, even within industries, from one firm to another. Although direct evidence of the degree of under- or overinvestment among nonprofit firms is largely lacking, there is strong indirect evidence suggesting that nonprofit firms in rapidly growing service industries, such as nursing care, have had their growth noticeably hampered by an inadequate supply of capital. ${ }^{70}$ At the same time, there is good reason to believe that in many cases nonprofit firms are substantially overcapitalized; this often seems to be the case today, for example, with nonprofit hospitals. ${ }^{71}$ Simply granting or denying income tax exemption will obviously fail to eliminate all such disparity in access to capital among nonprofit firms, or between nonprofit and for-profit firms. The exemption alone can only ameliorate, not eliminate, severe cases of capital constraint, while, in turn, denial of the exemption will in itself be inadequate to insure that a nonprofit does not accumulate capital far in excess of the efficient level of investment.

note 12, at 587-99. Moreover, whether organized as nonprofits, cooperatives, or whatever, membership organizations such as country clubs are presumably well situated to raise adequate amounts of capital through their members. See pp. 94-95 infra.

70. Studies of several service industries populated by both nonprofit and for-profit firms suggest that the ratio of nonprofit to for-profit firms varies inversely with the rate of growth in demand. Thus, the percentage of private nursing homes that are nonprofit has been shown to be (as of 1975) significantly lower in those states that have experienced rapid increases in their elderly population. $H$. Hansmann, The Importance of Property Tax Exemption as an Incentive for Organizing Services on a Nonprofit Basis (unpublished, October 1981) (on file with Yale Law Journal). Similarly, the change in the ratio of for-profit to nonprofit hospitals during the rapid expansion of the hospital industry in the 1960s for different states showed a significant positive correlation with the rate of growth in state population. Steinwald \& Neuhauser, The Role of the Proprietary Hospital, 35 LAw \& CONTEMP. PROB. 817, 828 (1970). Differences in access to capital seem to offer the most natural explanation for the difference in growth rates between nonprofit and for-profit firms in these cases. See id. at 828 . A lack of strong incentives for managers and entrepreneurs in the nonprofit sector to pursue rapid growth may also play a role here, however. See Hansmann, supra note 2, at 878-79.

71. See notes 98 \& 102 infra. 


\section{Dynamics of Nonprofit Growth}

In order to get a better grasp of the strengths and weaknesses of the capital formation rationale for the exemption, and to understand the consequences of the exemption in general, it helps to focus on the dynamics of competition in an industry potentially populated with both nonprofit and for-profit firms. The following discussion considers, in general terms, the form that this competition is likely to take, and the way in which tax policy is likely to affect such competition. A simple mathematical model that parallels this discussion is presented in the appendix, for purposes of further illustration. Readers whose taste for detailed economic analysis is limited, and who are not concerned with the fine points of the argument, can safely skip this section and the following section, and proceed directly to Section IX.

For simplicity, let us assume, initially, that the industry in question produces a service that is sold on the market for a price that, following the usual law of demand, is inversely related to the total amount of the service produced and offered for sale by the industry, and that receipts from the sale of this service are the only source of revenue for the producing firms, whether for-profit or nonprofit. Thus, for the moment we shall focus only on commercial nonprofits, and shall defer questions of donative financing. Let us also assume, initially, that the nature and quality of the service do not depend upon whether it is provided by a nonprofit or a for-profit firm.

\section{A. For-Profit Firms Only}

To begin with, suppose that the industry is populated only with forprofit firms. Whether the industry is taxed or not, assuming that there are no substantial economies of scale or other obstacles to effective competition, the forces of competition will tend to lead the industry to expand quickly to the level of production at which all firms (or at least the marginal firms) are just breaking even. This is because additional capital can presumably be obtained readily through the equity market so long as the industry has not yet reached the point at which firms are just breaking even. At this level of production, the price that the service brings on the market will have dropped to the point where each firm is earning just enough from sale of the service to permit it to pay the prevailing market rate of return for all inputs that it employs, including a competitive wage for its workers and a competitive return on invested capital.

If, as is commonly supposed, the corporate income tax, when applied to a for-profit firm, essentially serves as a tax on the return paid to investors of capital, then the effect of imposing such a tax on the industry is to raise the price at which the service must be sold in order for the firm to break 
even. It follows that the imposition of the corporate tax on this industry will reduce somewhat the amount of the service that is produced and sold. $^{72}$

\section{B. Nonprofit Firms Only}

Now consider, alternatively, what is likely to happen if the service in question is produced only by nonprofit firms.

Capital owned by a nonprofit firm - whether obtained through donations or through retained earnings-is essentially free to the firm, in the sense that the firm need pay no return on that capital, and can turn it to no uses other than production of the services for which the firm was organized. ${ }^{73}$ The only capital expenses that a nonprofit must cover, therefore, are (1) interest on borrowed capital and (2) depreciation. To simplify matters, assume for the moment that nonprofit firms do not have the option of borrowing capital. Thus, the only expense facing the nonprofit firms in our hypothetical industry, in connection with a given stock of capital, is the depreciation on that capital.

It follows that a nonprofit firm will be able to break even, while maintaining its current level of production, so long as its income from sale of its services is sufficient to cover the expense of capital depreciation plus wages and other variable costs. If demand for the service is high enough relative to the total amount of the service that the existing firms in the industry can produce, those firms will be able to charge more than enough to cover such expenses, and thus will be able to accumulate net earnings with which to purchase additional capital that can be used to expand production in the future. Indeed, since a nonprofit cannot distribute its net earnings, it has little alternative but to spend its net earnings on additions to its capital stock, and, conversely, firms can add to their capital stock only to the extent that they are able to accumulate such net earnings (again, ignoring for the moment the possibility of using debt).

In the absence of taxes, firms in the industry can therefore be expected to expand until total production of the service has reached the point where price has dropped to a level at which each firm has just enough income to cover the costs of depreciation on capital plus noncapital costs such as

72. The effects of the corporate income tax, viewing it as an excise on corporate capital, are explored in Harberger, supra note 41.

It has recently been suggested that the corporate tax may not, in fact, act as an excise on corporate capital, but rather as a pure profits tax. The implications of this alternative view are explored in Section VIII.E, p. 85 infra.

73. We shall ignore here, and throughout, the possibility that a nonprofit might choose to, and be permitted to, invest in unrelated businesses. Allowing for such investment behavior would complicate the analysis considerably without adding importantly to the basic points being made in this Article. Sec Section X, pp. 92-93 infra. 
wages-that is, to the level at which the firms have no net earnings to devote to additions to capital. ${ }^{74}$ As long as aggregate demand for the service does not change, this is then the point at which the industry will maintain itself.

The total amount of the service that is produced at this point will, it should be noted, depend somewhat on the preferences of the managers of the nonprofit firms. The reason for this is that the firms will generally be confronted with a tradeoff between present and future production. A nonprofit firm with a given amount of capital can, on the one hand, use the amounts of labor and other variable factors that maximize net earnings, and thus maximize the amount of capital that can be purchased for the purpose of expanding future production. Or, on the other hand, the firm can simply increase the amount of labor and other variable factors that it uses in the current period to the point where the expenses associated with these factors are so large as to consume all potential profits, and thus maximize current production of the service, while providing no opportunity for expansion in the future. Put differently, the "price" that a nonprofit firm pays for the capital it uses for expansion is not the market rate of return, but rather the amount of current production that must be foregone in order to accumulate net earnings. ${ }^{75}$

The point at which the nonprofit firms in the industry stop expanding, therefore, will depend on the extent to which the managers of the firms are prepared to trade off present for future production. A strong relative preference for current production will lead the firms to stop growing at a relatively low level of total industry production (and a high price for the service, which is necessary to cover the high cost of producing with the inefficiently low capital-labor ratio that will characterize such firms), while a strong preference for future production will lead the firms to grow more quickly, and to stop growing only when total industry production is so large, and market price has fallen so low, that a very large amount of present production would have to be foregone in order to obtain the profits necessary to purchase the capital required for even a small amount of

74. There is another option open to nonprofit firms facing a high market price: they can sell their service, not at the market price, but rather at a lower price that is at or below the level that just covers variable costs plus depreciation, and hence accumulate no earnings with which to acquire additional capital for purposes of expansion. (Indeed, if the price thus chosen is below that which is required to cover depreciation on the existing capital, the firms will actually shrink over time.) Since, at such a price, there will be excess demand for the service, firms electing this approach will need to ration their services. This alternative will not be explored here, in part because, in a sense, it does not really add anything new to the problem. We can simply view the service provided by nonprofits that behave this way not as, say, nursing care, but rather as nursing care plus a subsidy of $x$ dollars, the cost of which is $\boldsymbol{x}$ dollars more than the cost of providing nursing care alone; the analysis offered in the text then applies without modification.

75. This tradeoff does not appear in the model presented in the Appendix, since that model assumes a fixed capital/labor ratio. 
future expansion. ${ }^{76}$

Now suppose that a tax is levied on the net income of the nonprofit firms (using the definition of net income offered in Section II.A). ${ }^{77}$ What effect will such a tax have on production in our all-nonprofit industry? Note, to begin with, that there will be no tax liability for a nonprofit firm that is not growing, but rather is spending all of its income to cover the costs of capital depreciation and variable costs such as wages. Thus, when the industry has finally reached its equilibrium level of development, in which all firms in the industry are just breaking even, there will be no tax revenues forthcoming from the industry. In contrast, for-profit firms must pay taxes even when they have reached the equilibrium point at which they no longer have an incentive to expand. Thus, income taxes are not a cost to nonprofit firms in equilibrium, and hence have no direct effects on the level of production that the nonprofit firms will ultimately reach, in contrast to the case with for-profit firms. In this respect an income tax levied on a nonprofit differs from a property tax or a sales tax, both of which yield positive tax liabilities for the firm even when the firm is not growing and is just bringing in enough total revenue to cover its costs of production (including taxes).

On the other hand, subjecting nonprofit firms to income taxation will have an indirect effect on the behavior of the firms. Since such a tax is effectively a tax on retained earnings, it will reduce the rate at which a nonprofit firm can expand. For example, at a rate of fifty percent, an income tax would tax away half of a nonprofit's retained earnings, and consequently reduce by half the amount of capital that a nonprofit could purchase with a given amount of retained earnings. Thus, an all-nonprofit industry would expand toward its equilibrium level of production more slowly than it would without the tax. Moreover, the tax has the effect of worsening the tradeoff between present and future production that confronts a nonprofit firm. With a fifty percent tax rate, twice as much present production must be sacrificed for a given increase in future production as would be the case without the tax. The result is that the managers of nonprofit firms will find it less attractive to trade off present for future production at any given level of production, and will put a stop to their firm's expansion at a lower level of total industry production than they would otherwise. Thus, the tax can be expected to reduce not only the

76. Owners and managers of for-profit firms, in contrast, are faced with the tradeoff of present for future profits, and since, unlike nonprofits, they have relatively free access to the capital markets, they have an incentive to press investment within the firm just to the point at which that tradeof- which is the internal rate of return on the firm's investments-equals the rate of return (interest rate) on capital in the market. Thus, the capital market constrains the choice of present versus future production in a for-profit firm more strongly than it does in a nonprofit firm.

77. See pp. 58-62 infra. 
rate at which nonprofit firms grow toward their equilibrium level of production, but also the aggregate amount of the service that is produced at equilibrium..$^{78}$

\section{G. Both Nonprofit and For-Profit Firms}

Consider, finally, an industry in which, to begin with, there are only for-profit firms, operating, as a consequence of competition, at the breakeven (equilibrium) point as described above. Suppose, then, that one or more nonprofit firms enter the industry, each with some initial supply of capital. And let us assume, for the time being, that these nonprofit firms can produce the service in question just as efficiently as the forprofit firms in the industry - that is, they can produce a unit of the service with the same amounts of inputs (capital, labor, etc.) as their for-profit counterparts. Finally, let us assume also, for the moment, that there are no income taxes for either for-profit or nonprofit firms.

At the prevailing market price at which the for-profit firms are just breaking even, the nonprofit firms will be able to produce net earnings, since, unlike the for-profit firms, they need pay no return on the capital that they are employing. What the nonprofit firms proceed to do at this point will depend on the preferences of the firms' managers.

If, on the one hand, the managers of the nonprofit firms have a reasonably strong preference for future expansion over present production, the nonprofit firms will proceed to accumulate net earnings and to grow. The resulting increase in total industry production will tend to drive down the market price for the service, which in turn will cause for-profit firms to start losing money and to begin leaving the industry. By this process the nonprofit firms will continue to supplant for-profit firms until there are only nonprofit firms producing the service. The nonprofit firms will continue to have net earnings, and to expand, however, even beyond the point at which all for-profit firms have been driven from the industry. Such expansion will stop only when the nonprofit firms have increased total industry production to an all-nonprofit equilibrium, as described above, with greater total production and lower market price than that which prevailed before the nonprofit firms took over the industry.

If, on the other hand, the managers of the nonprofit firms have a strong

78. These effects will be diminished if depreciation allowances exceed actual decline in value for capital investments. See note 23 supra. Even if $100 \%$ of the cost of a capital asset could be deducted in the year of its purchase, however, the consequences of taxing nonprofits described here would continue to some extent if nonprofit firms found it necessary-as presumably they often still would-to accumulate cash reserves over several years in order to finance substantial capital expenditures, for those cash accumulations would still be taxable, and the offsetting deduction for the purchase of the asset could not be taken until the asset was actually purchased. (On such matters of timing, see note 31 supra.) 
preference for producing as much of the service as possible in the present, without much concern for foregone opportunities for future growth, then they may burn up all of their potential profits by hiring more labor and other variable factors with which to expand current production. The nonprofits will not grow at all, but rather will simply coexist with the forprofit firms at the market price and total level of industry production that would prevail if there were only for-profit firms in the industry. Indeed, if the managers of the for-profit firms were to push their preference for present as opposed to future production to extremes, they might even fail to accumulate sufficient funds to cover depreciation on their existing capital stock, and hence the nonprofit firms would actually decline and would eventually disappear entirely, leaving the industry to the for-profit firms alone.

If the for-profit firms in the industry are subject to income taxation, then it will be more likely that the nonprofit firms will ultimately take over the industry. The reason for this is simply that, as we have seen, imposing a tax on the for-profit firms increases the price at which they must sell their services, and at this higher price the nonprofit firms will face large potential profits and, thus, more favorable opportunities for expansion.

If an income tax is then extended to the nonprofit firms in the industry, it will reduce the likelihood that the nonprofits will ultimately drive out the for-profit firms. As indicated by our earlier analysis, however, the consequences of the tax in this respect will be only indirect. When the firms in the industry, both nonprofit and for-profit, have stopped growing-and hence the industry is in a state of equilibrium-the nonprofit firms will be paying no income taxes, whether they have succeeded in taking over the whole industry or are simply coexisting with the for-profit firms. Because the tax does, however, make the tradeoff between present and future production for the nonprofit firms less attractive than in the absence of the tax, it will reduce the incentive for the nonprofit firms to expand production at any given prevailing market price, and hence will reduce the likelihood that the industry will be taken over by the nonprofits. Moreover, the tax will slow the rate at which the nonprofits grow, and hence will extend the time it takes for the nonprofit firms to attain their equilibrium level of development, including takeover of the industry, if that is the equilibrium result.

We see, then, that exemption of nonprofit firms from corporate income taxation is not really a subsidy in the usual sense. In equilibrium, nonprofit firms will pay no income taxes whether they are included in the tax base or not. In this respect, as already noted, exemption from the corporate income tax does not give nonprofit firms an advantage over their for- 
profit counterparts that is of the same character as that which results when nonprofit firms are exempted from a property tax or a sales tax to which for-profit firms are subjected. On the other hand, exemption from income taxation does permit nonprofit firms to grow faster than they could if they were taxed, and it does give them an incentive to grow, and ultimately perhaps to take markets away from for-profit firms, in a broader range of conditions than would be the case without the exemption. ${ }^{79}$

\section{Relaxing the Assumptions}

Let us now relax some of the assumptions on which the discussion so far has been premised, in order to understand the consequences of tax exemption in a broader and more realistic range of circumstances.

\section{A. Growing Demand}

We have been assuming so far that demand in the industry is static. If, however, demand for the service is steadily increasing, then the rate at which nonprofits are able to take over an industry initially populated by for-profit firms will be reduced. In fact, if demand for the service increases faster than the rate at which the nonprofits are able to grow, then the nonprofits will not be able to take over the industry at all, and there will continue to be a mix of for-profit and nonprofit firms in the industry so long as demand continues to expand at such a rate. Likewise, if an industry is initially populated only with nonprofit firms, and then the demand for the industry's service begins to grow rapidly, for-profit firms may be able to enter the industry alongside the nonprofit firms, since only the forprofit firms will face no constraint on the amount of capital they can obtain, at market rates of return, for purposes of expansion. The varying percentages over time of nonprofit and for-profit firms in the hospital industry, for example, seem to be explainable at least in part by such variations in the rate of growth in demand..$^{80}$

It follows that tax exemption for nonprofits is likely to have its most pronounced effects in an industry in which demand is expanding. The

79. This discussion, it should be noted, ignores questions of risk. The corporate income tax, if extended to nonprofits, might have the effect of making the government a partner in bearing the risks of the enterprise, and consequently could lead nonprofits to undertake more risky ventures than they otherwise would. See Stiglitz, The Effects of Income, Wealth, and Capital Gains Taxation on RiskTaking, 83 Q.J. ECON. 263 (1969). If, in the absence of the tax, nonprofits tend to be excessively risk averse, which may in fact be the case owing to the inability of nonprofits to employ equity financing, then imposition of the corporate tax on nonprofits could lead to an improvement in efficiency as far as risk-taking is concerned. Any welfare effects of this sort, however, seem likely to be swamped by the effects that are the focus of the discussion in the text.

80. See Steinwald \& Neuhauser, supra note 70 , at 828. 
exemption will have a strong influence on the length of time required for nonprofits to catch up with demand growth, and, hence, on the balance between nonprofit and for-profit producers at any given moment.

\section{B. Relative Efficiency of Nonprofit Firms}

We have also been assuming that both nonprofit and for-profit firms can produce the service in question with the same efficiency. Typically, however, the differences in the form of organization will result in some disparity in efficiency.

In most industries nonprofit firms are probably less efficient than their for-profit counterparts, owing to the decreased incentives for cost minimization that result from the absence of the profit motive, ${ }^{81}$ and to the absence of special circumstances-in particular, contract failure-that give nonprofits a countervailing efficiency advantage. ${ }^{82}$ If this disparity in efficiency is so large that, at the breakeven price for for-profit firms, nonprofit firms cannot even cover their non-capital costs, then nonprofit firms will not be able to survive in competition with for-profit firms. At more modest levels of inefficiency, however, nonprofits may be able not only to survive in competition with for-profit firms, but also to grow and perhaps even eventually take over the industry, since nonprofits are spared the necessity of paying a competitive rate of return on the capital they employ, and this may compensate for their inefficiency. Whether or not the for-profit firms are subject to income taxation will have an effect here: The higher the rate of tax levied on the for-profit firms, the less efficient the nonprofit firms need be in order to compete with them effectively.

The ability of relatively inefficient nonprofits to survive in competition with for-profit firms will not, however, depend directly on whether or not the nonprofits are subject to income taxation. Rather, as we have seen, nonprofit firms will pay no income taxes in equilibrium, and hence the exemption will not affect their ability to cover their costs at any given price level for the service that they sell. The exemption will only affect the rate at which nonprofits can grow, and the incentive to grow that faces the firms' managers.

Alternatively, it may be that owing to problems of contract failure, in

81. Although the separation of ownership and control in large business corporations may create some opportunity for managerial inefficiency, the market for corporate control presumably places some bounds on the extent to which such inefficiency can go. See Manne, Mergers and the Market for Corporate Control, 73 J. POL. ECON. 110 (1965). The management of a nonprofit corporation, in contrast, is commonly self-appointing both in law and in fact, and thus is not only beyond the reach of the market for corporate control, but is in fact directly responsible to nobody who has a direct interest in the efficiency with which the organization is managed. See generally Hansmann, supra note 2, at 878.

82. See note 57 supra. 
producing the service in question, nonprofit firms are more efficient than their for-profit counterparts. ${ }^{83}$ In this case the nonprofit firms in the industry will clearly be able to survive and grow at the price that represents the breakeven point for the for-profit firms. ${ }^{84}$ Only if the managers of the nonprofit firms show a strong preference for present production over future expansion, or if demand for the service is growing faster than the nonprofit firms can accumulate earnings, will nonprofit firms fail ultimately to supplant all the for-profit firms in the industry. This will be true, moreover, whether or not the for-profit or the nonprofit firms in the industry are subject to income taxation, though if the for-profit firms are taxed, and if the nonprofit firms are exempt, nonprofit firms will be able to expand at a greater rate, and will have more incentive to expand, than they would otherwise.

\section{Availability of Debt}

The preceding discussion has been based on the assumption that nonprofit firms do not have access to debt, but rather must obtain all of their new capital through retained earnings. This is, of course, unrealistic. Nevertheless, the availability of debt capital only partially alters the basic conclusions reached above.

If debt capital were available to nonprofit firms without restriction, then nonprofits would be able to expand rapidly to the point where price for the service has fallen to the level at which it just covers variable costs plus the interest cost of debt capital - which would be roughly the efficient level of operation. Thus, the availability of tax exemption would not affect the speed with which nonprofits could expand to the efficient level of production. Nonprofit firms would, however, still be able to expand beyond this point, using internally generated capital, and such expansion would be governed by the same considerations discussed above.

Of course, it is equally unrealistic to think that nonprofits have unlimited access to debt capital. Rather, nonprofits are, as noted earlier, ${ }^{85}$ likely to be able to secure debt financing for a part, but by no means all, of their capital needs. In general, then, we can say that, to the extent that nonprofits have access to debt capital, the importance of tax exemption in

83. See note 69 supra.

84. Or, what is effectively the same thing, the nonprofit firms will be able to charge a higher price than will for-profit firms for the same quality of service, since consumers will feel less impelled to undertake costly measures to verify for themselves the quality of the firm's services when the firm is nonprofit than when it is for-profit (or, put differently, will "trust" the nonprofit providers more than the for-profit providers). See note 57 supra.

85. See p. 73 supra. 
Nonprofits and the Income Tax

facilitating the expansion of nonprofits to their efficient level of production will be reduced.

\section{Donative Nonprofits}

For purposes of simplicity and clarity, we have considered here only strictly commercial nonprofits. All that has been said, however, applies with equal force to donative nonprofits. We need simply view the donations that the firms receive as the price that the public is prepared to pay for the services that the firms produce.

\section{E. Alternative Views of the Corporation Tax}

The preceding discussion has assumed that the corporate income tax, as applied to business corporations, has the effect of raising the pre-tax rate of return that a corporation must seek on its investments. It has recently been suggested, however, that the corporate tax may in fact act as a tax only on pure profits, ${ }^{86}$ having no effect on a firm's investment policy. ${ }^{87}$

The general conclusions drawn here continue to apply under this alternative view of the corporate tax. The effects of extending the tax to nonprofits remain as described above. It will no longer be the case, however, that the ability of nonprofits to survive in competition with for-profit firms will be enhanced by the application of the tax to the for-profit firms, since the tax will have no effect on the behavior of the latter firms.

\section{Implications for Tax Policy}

We are now in a position to formulate the appropriate goals for tax policy, and to consider whether exempting some or all nonprofits from corporate income taxation will bring us closer to those goals.

\section{A. Policy Objectives}

From the perspective of economic efficiency, it is desirable to have nonprofit rather than for-profit firms in an industry if and only if the nonprofit firms are more efficient than for-profit firms in producing the service in question. Since the primary efficiency advantage that nonprofit firms have over for-profit firms appears to be in responding to contract failure, this means that, in general, it is desirable to have nonprofit firms develop where contract failure is a serious problem (and one that cannot

86. "Pure profits" are earnings in excess of what is necessary to pay for all factors of production, including labor, capital, and entrepreneurial talent.

87. See Stiglitz, supra note 10. 
be dealt with by other means ${ }^{88}$ ), and not elsewhere.

Assuming that circumstances are such that nonprofit firms are the most efficient producers of the service, the service should generally be produced in that quantity at which the price that it brings just covers the marginal costs of production, such as the costs of the capital, labor, and other factors used in producing the service. Capital, in particular, should be employed in the industry just up to the point at which its marginal productivity equals the costs of diverting the capital from other industries. If there were no tax imposed on the returns to capital in other industries, this would mean simply that capital should be used in an industry populated with nonprofits just to the point where its marginal productivity equals the rate of return that capital is bringing in for-profit industries. With a tax on the return to capital in other industries-in the form of the corporate income tax and the personal income tax-the appropriate standard becomes more ambiguous. A rough approximation is that capital in the nonprofit industry should be used up to the point at which its productivity equals the before-tax rate of return being earned on capital in other industries. ${ }^{89}$

\section{B. Choosing an Appropriate Policy}

It follows that, if tax exemption for nonprofits is to be administered in accordance with the dictates of economic efficiency, two conditions should be satisfied before exemption is granted to the nonprofit firms in a given industry: (1) nonprofit firms must be more efficient producers of the service than are for-profit firms; and (2) the nonprofit firms in the industry must not have expanded to the point at which the productivity of the capital they employ has fallen below the before-tax rate of return being earned on capital in other industries.

As a practical matter, it usually will not be feasible to condition tax exemption for nonprofits on a judgment by the Treasury Department as to whether capital investment among nonprofit firms in particular industries has exceeded the efficient level. Such a criterion would be extremely difficult to administer. ${ }^{90}$ Consequently, the best that can be done in this

88. See Hansmann, supra note 2 , at $868-72$.

89. The ambiguity results from problems of second best deriving from the fact that the corporate tax distorts capital investment in for-profit firms, causing those firms to invest inefficiently small amounts of capital. Of course, if we accept the alternative view of the corporate tax (as applied to forprofit firms) as a tax only on pure profits, see p. 85 supra, then there is no difference between the before-tax and the after-tax marginal rates of return among for-profit firms, and this problem disappears.

90. It would be very hard to determine with any precision the effective marginal rate of return to investment among nonprofit firms in any given industry; a rough estimate is probably all that could be obtained. Administrative decisions based on rough empirical estimates, however, would always be subject to attack. Moreover, policymaking would be complicated by the fact that the rate of return to 
area is probably to focus primarily on the first of the two criteria offered here, ${ }^{91}$ and require as a condition of exemption simply that there be convincing evidence that, in the industry in question, nonprofit firms are, owing to contract failure, ${ }^{92}$ more efficient than their for-profit counterparts. ${ }^{93}$

Of course, this is not the way that tax policy in this area is, or ever has been, explicitly formulated. Nevertheless, the results achieved with current policy represent at least a crude approximation to those that would be reached following this approach. Thus, the exemption is frequently denied, as it should be, to commercial nonprofits that produce, distribute, or retail standard agricultural and industrial goods, and to those that offer simple services. ${ }^{94}$ In such industries it seems extremely unlikely that nonprofit firms are more efficient than for-profit firms, and hence any level of nonprofit development would be inefficient. There would obviously be little point, for example, in granting the exemption to a nonprofit hardware store.

On the other hand, the exemption is quite solidly entrenched for most types of donative nonprofits. ${ }^{95}$ This, too, is consistent with the efficiency criterion just suggested. Donative nonprofits, almost by definition, typically provide services that are delivered to third parties or are public goods, and that as a consequence are attended by severe contract failure.96

capital for nonprofit frrms in an industry will often vary from region to region and even firm to firm.

91. This is not to say, however, that the second criterion need be ignored entirely. See, e.g., note 98 infra.

92. If nonprofit firms could be demonstrated to have important efficiency advantages over forprofit firms under identifiable conditions other than contract failure, similar reasoning could justify granting tax exemption to nonprofit firms in those circumstances as well. See note 69 supra.

93. Of course, focusing just on the first of the two criteria suggested here would yield an unsatisfactory result unless in fact the majority of firms that meet the first criterion meet the second criterion as well. There is reason to believe, however, that this is the case. As discussed below, there seem to be two broad classes of nonprofits that arguably meet the first criterion: donative nonprofits, and commercial nonprofits that provide complex personal services. As discussed in note 98 infra, donative nonprofits as a class seem more likely than not to suffer from inadequate access to capital. And demand for the services of the second class of nonprofits-which include, for example, nursing homes, day care centers, and family counseling clinics-has been growing sufficiently rapidly in recent decades, see, e.g., note 16 supra (nursing homes), that it seems unlikely that the nonprofit firms in the industries involved are, in general, overcapitalized.

94. See Federation Pharmacy Serv., Inc. v. Commissioner, 625 F.2d 804 (8th Cir. 1980) (exemption denied to nonprofit pharmacy); Senior Citizens Stores, Inc. v. United States, 602 F.2d 711 (5th Cir. 1979) (exemption denied to nonprofit store selling used clothing, furniture, and household appliances); People's Educ. Camp Soc'y, Inc. v. Commissioner, 331 F.2d 923 (2nd Cir. 1964), cert. denied 379 U.S. 839 (1964) (exemption denied to nonprofit summer resort); B.S.W. Group, Inc. v. Commissioner, 70 T.C. 352 (1978) (exemption denied to nonprofit consulting firm). But see Metropolitan Detroit Area Hosp. Serv., Inc. v. United States, 445 F. Supp. 857 (E.D. Mich. 1978) (exemption granted to nonprofit corporation selling laundry services to governmental and nonprofit hospitals).

95. Because, as noted immediately below, donative nonprofits typically provide services that either have desirable redistributive effects or are public goods, it is relatively easy to justify exemption for such organizations on the basis that their services can be classified, for example, as "charitable," I.R.C. § 501(c)(3), "civic," or "social welfare," I.R.C. \& 501(c)(4). See Hansmann, supra note 2, at 514.

96. See pp. 69-70 supra. 
Indeed, the wisest course is probably just to assume, absent evidence to the contrary, that all nonprofits that receive a substantial fraction ${ }^{97}$ of their income in the form of donations are operating in an environment of contract failure, and therefore merit the exemption on efficiency grounds. Such a policy-which is essentially what we have now-may well grant the exemption to some organizations for which it is unjustified. But a more refined approach to donative nonprofits would probably not be worth the increase in ambiguity and administrative complexity it would entail. ${ }^{98}$

Between these two extremes-donative nonprofits on the one hand, and commercial nonprofits that provide simple standardized services on the other-we have the troublesome category of commercial nonprofits that provide complex personal services such as education, hospital care, nursing care, and day care. For which, if any, of these services are the fiduciary qualities of the nonprofit form so effective and necessary that tax exemption can be justified on efficiency grounds? It is difficult to offer an authoritative answer to this question, since at present there exist little solid data concerning the relative performance of nonprofit and for-profit firms in providing such services.

For most of these services-including, in particular, nursing care, day care, and education (including vocational education)-continuation of the current policy favoring exemption seems justifiable, though perhaps not compelling. There is, to be sure, debate as to whether in fact the commercial nonprofit firms in these industries, on average, serve consumers better in any important respect than do their for-profit counterparts. ${ }^{99}$ Yet in

97. Just because an organization receives an occasional small donation, though it relies upon sales receipts for the great bulk of its income, does not mean that it should be considered "donative" for purposes of the analysis offered here. The mere presence of donative income should be considered presumptive evidence of contract failure only when the organization involved is heavily dependent upon such income.

98. Fortunately, the two criteria suggested above for granting the exemption-relative efficiency vis-a-vis for-profits, and existing extent of capital accumulation-often go hand in hand. Not only is it easier to make the case that nonprofit firms are more efficient than their for-profit counterparts would be when the nonprofits in question are donative than when they are commercial, but further, it seems in general less likely that donative nonprofits will exceed the efficient level of capital accumulation than that commercial nonprofits will do so. The reason for this is that the services of donative nonprofits commonly have-at least to some degree, and at least for a limited group of individuals-the characteristics of a public good, and consequently free-rider incentives are likely to keep the level of donations, and hence the level of capital accumulation and of production, below the efficient level in donative nonprofits. On the other hand, it is not always the case that donative nonprofits are inefficiently constrained by lack of capital. Boys' Town, for example, evidently managed to accumulate, through solicitation of donations, an amount of capital far in excess of any reasonable needs. See N.Y. Times, April 16, 1974, at 41, col. 1.

99. For example, while some have argued that the widespread abuses that evidently characterize the nursing home industry are primarily attributable to the for-profit firms in that industry, see Regan, Quality Assurance Systems in Nursing Homes, 53 J. URB. L. 153, 210-14 (1975); Shulman \& Galanter, Reorganizing the Nursing Home Industry: A Proposal, 54 MILBANK MEMORIAL FuND Q. 129 (1976), others have argued that, overall, there is not much to choose between nonprofit and for- 
each of these areas nonprofit firms represent a significant fraction of the industry, and this has evidently occurred, in large part, because a substantial subset of consumers feels more comfortable patronizing a nonprofit. Until we have better data suggesting that these consumers are mistaken, there is something to be said for continuing the exemption and thus helping to insure that such consumers continue to have the option of patronizing a nonprofit.

On the other hand, it is not at all clear that there is justification for the relatively recent decision to exempt nonprofit hospitals from taxation even if they provide no research, teaching, or subsidized care for indigents; that is, even if they are operated as strictly commercial.nonprofits. ${ }^{100}$ Problems of contract failure do not seem important in the case of most hospital services. The continued predominance of the nonprofit form in this industry seems, instead, to be attributable to historical and financial factors largely unrelated to the relative efficiency of for-profit and nonprofit institutions. ${ }^{101}$ Moreover, there is evidence that, in general, the hospital industry is already overcapitalized. ${ }^{102}$ Thus, the hospital industry arguably fails both the criteria suggested above for administering the exemption. The current policy of exempting virtually all nonprofit hospitals may simply further encourage what already appears to be excessive capital investment in this sector. ${ }^{103}$

profit firms in this regard, see M. MENDELSON, TENDER LOVING GREED 195-212 (1974).

100. See p. 61 supra.

101. See Clark, supra note 58, at 1459-62; Hansmann, supra note 2, at 866-68.

102. The perception that the hospital industry is overcapitalized was a major stimulus to the passage of the National Health Planning and Development Act of 1974, Pub. L. No. 93-641, 88 Stat. 2225, codified with amendments at 42 U.S.C. $\$ 300 \mathrm{~m}$ and scattered sections (West Supp. 1981). The Senate committee that endorsed passage of that Act noted that "[t]here is convincing evidence from many sources that overbuilding of facilities has occurred in many areas . . . [B]y 1975, over 67,000 unneeded hospital beds will be in operation throughout the United States." S. REP. No. 93-1285, 93d Cong., 2d Sess., reprinted in [1974] U.S. CODE CONG. \& AD. NEWS 7842, 7878-79. Similar findings were made by the Senate committee in endorsing strengthening amendments to the Act in 1979. S. REP. No. 96-96, 96th Cong., 1st Sess., reprinted in [1979] U.S. CODE CONG. \& AD. NEWS 1306, 1358 ("[T]here are at least 130,000 unneeded hospital beds throughout the United States.") The Act itself states that " $t$ the Congress finds that . . . there is duplication and excess supply of certain health services and facilities, particularly in the case of inpatient health services." 42 U.S.C. $\S 300 \mathrm{k}-2(\mathrm{~b})(1)$ (Supp. III 1979).

103. Clark, supra note 58 , argues that nonprofit hospitals offer no apparent efficiency advantages over their proprietary counterparts, and that legal rules that have the effect of subsidizing the nonprofit as opposed to the for-profit form should be made neutral with respect to these two organizational forms. He argues, in particular, that property tax exemption should be denied to nonprofit hospitals, but does not discuss exemption of nonprofit hospitals from corporate income taxation. Id. at 1473-77.

As the discussion offered here in the text suggests, it is not entirely easy to fashion corporate income taxation so that it is "neutral" between the nonprofit and for-profit forms of organization. In particular, the corporate income tax is not necessarily made neutral between these two organizational forms simply by denying an exemption to nonprofits. If the nonprofits in the industry in question are inefficiently capital constrained, extending the corporate income tax to nonprofits on the same terms as it is applied to for-profits may seriously aggravate this handicap. On the other hand, the reverse is true if for some reason (as may be the case in the hospital industry) capital accumulation among nonprofit 


\section{The Significance of For-Profit Competitors}

The preceding analysis throws some light on an issue that has long been a source of confusion in the administration of the exemption for nonprofits: the relevance of the fact that a nonprofit competes with for-profit firms providing similar services. Such competition is frequently cited as a justification for denying exemption. For example, in sustaining the recent refusal of the IRS to grant an exemption to a nonprofit consulting firm, the Tax Court relied on the fact that the firm's business was "of the sort which is ordinarily carried on by commercial ventures organized for profit," and remarked that the firm was "in competition with commercial businesses."104 "Competition with commercial firms," said the Court, "is strong evidence of the predominance of non-exempt commercial purposes." ${ }^{105}$ Yet, as at least one court has noted, ${ }^{106}$ the mere fact that a firm competes with for-profit suppliers of the same service cannot be sufficient to justify denial of exemption, since many types of organizations that have long benefited from the exemption, including hospitals, schools, nursing homes, and day care centers, regularly engage in such competition. ${ }^{107}$

From the discussion above of the dynamics of competition between nonprofit and for-profit firms, it should be clear that the mere presence or absence of for-profit competitors should not be determinative in awarding exemption to a nonprofit. As we have seen, it is quite possible that nonprofit firms, even though less efficient than their for-profit counterparts, could completely take over an industry. ${ }^{108}$ Conversely, in industries in which demand is expanding rapidly one might expect to see a large proportion of for-profit firms even if they are less efficient than nonprofits, simply because the nonprofits cannot obtain the capital necessary for rapid expansion. It follows that, in determining whether nonprofit firms in a given industry should have the benefit of the exemption, there is no alternative to inquiring directly into the role that the nonprofit firms play in that industry. If it seems likely that the nonprofit form represents a reasonable response to problems of market failure in that industry, then ex-

firms has already exceeded the efficient level. (Note, too, that to some extent the same observations apply to exemption from property taxation, which is itself a form of subsidy to capital accumulation.)

104. B.S.W. Group, Inc. v. Commissioner, 70 T.C. 352, 358 (1978).

105. Id. See also Federation Pharmacy Serv., Inc. v. Commissioner, 625 F.2d 804, 809 (8th Gir. 1980) (exemption denied a nonprofit pharmacy on grounds that, inter alia, "it is engaged in competition with for-profit pharmacies"); People's Educ. Camp Soc'y, Inc. v. Commissioner, 331 F.2d 923, 931 (2nd Cir.), cert. denied, 379 U.S. 839 (1964) (fact that nonprofit resort was "in active competition with other such businesses" cited among reasons for denying exemption).

106. Metropolitan Detroit Area Hosp. Serv., Inc. v. United States, 445 F. Supp. 857, 861 (E. D. Mich. 1978).

107. For example, roughly $75 \%$ of all nursing homes in the United States are proprietary. Nevertheless, nonprofit nursing homes, even when (as is commonly the case) they are operated as commercial entrepreneurial nonprofits, have been exempted from income taxation. See note 16 supra.

108. See p. 83 supra. 
emption is warranted under the relative efficiency test suggested above. If, alternatively, the nonprofit firms seem to serve no function that cannot be served as well or better by proprietary firms, then the case for exemption fails.

In short, the right question to ask in deciding whether to grant an exemption is whether the same service could be provided as well by forprofit firms. The presence of for-profit competitors may well provide evidence in such an inquiry. It is wrong, on the other hand, simply to inquire whether the nonprofit firms in question are in competition with forprofit firms, since in the presence of market failure competition alone cannot be relied upon to sort out the efficient from the inefficient firms.

\section{Redistribution and the Provision of Public Goods}

The analysis so far has focused on the existence of contract failure as a prerequisite to granting income tax exemption to nonprofit firms in any given industry. We must now ask whether there are other, independent justifications for granting the exemption. In particular, if a nonprofit organization provides services that redistribute wealth in a socially desirable manner (as by aiding the poor), or that are public goods in some other important respect, does this in itself justify exemption, quite apart from questions of contract failure?

Note, to begin with, that most nonprofits that provide aid to the poor or other public goods are donative nonprofits, and thus presumably operate under cirumstances of substantial contract failure. ${ }^{109}$ The exemption can, therefore, be justified for such organizations on that basis alone. ${ }^{110}$

Suppose, however, there were a commercial nonprofit that sold to the poor goods or services, such as food or housing, that were not characterized by contract failure. Would the exemption be justified for such an organization if society felt that such services should be subsidized for the poor? Perhaps, but the case is not a strong one, for in these circumstances there would be no reason to confine the subsidy to nonprofit firms. Indeed, in the absence of contract failure it might be inefficient to provide a selective subsidy to nonprofit providers, since they might well be less efficient than their for-profit competitors. ${ }^{111}$

Similar logic applies to other privately sold services that, for some rea-

109. See p. 87 supra.

110. Note, too, that the second criterion for exemption offered in Section IX.B-the current extent of capital investment-is also likely to be satisfied for nonprofit organizations engaging in socially desired production of public goods. The mere fact that greater production of these goods is considered socially desirable indicates that they are presently being supplied at a suboptimal level, which in turn suggests that there is probably too little investment, from an efficiency point of view, in the capital facilities necessary to produce them.

111. See p. 87 supra. 
son (such as the presence of public good attributes), are likely to be undersupplied unless subsidized. Vaccinations and, perhaps, vocational education are examples of such services. ${ }^{112}$ Absent contract failure, there seems no reason to have a subsidy targeted particularly at nonprofit producers - much less a subsidy that is designed to be proportional to retained earnings.

\section{E. How Strong a Rationale?}

It should be emphasized that, even if the exemption were administered more in accordance with the policy guidelines suggested above, it would remain an extremely crude mechanism for dealing with problems of capital formation in the nonprofit sector. ${ }^{13}$ Thus, the strength of the capital subsidy rationale for the exemption should not be overstated. All that is being argued here is that (1) this rationale is the best justification that can be given for the exemption, and (2) it is an adequate rationale for the exemption in that, so long as the categories of organizations that qualify for the exemption are intelligently delineated, on the whole we are probably better off with the exemption than without it.

\section{Some Unexamined Issues}

The preceding analysis has assumed that a nonprofit's net earnings will always be reinvested in production of the basic services that the organization was formed to provide. If a nonprofit chooses to invest some of its net income in other unrelated industries with the aim of deriving profits that are to be used for financing the nonprofit's basic services only at some point in the future, new issues arise. Thus, simple conclusions cannot be drawn directly, on the basis of the preceding analysis, concerning the wis-

112. Vocational education may be undersupplied (or, rather, underconsumed) as a result of obstacles facing prospective students in borrowing against their future incomes. Cf. Hansmann, supra note 2, at 859-62 (discussing imperfections in loan markets for higher education).

113. The federal government could presumably use devices other than tax exemption to help alleviate capital shortages confronting nonprofits. Capital grants, loans, or loan guarantees, for example, would provide a much more direct response to the problem. Such devices have, in fact, sometimes been used. Capital grants were provided to hospitals from the 1940's until the 1970's under the HillBurton program. See THE NATION'S HEALTH FACILITIES, TEN YEARS OF THE HILl-BURTON HOSPI. TAL AND MEdical Facilities PrograM, 1946-56 (Public Health Service Pub. No. 616, 1958). Similarly, capital grants, loans, and loan guarantees have been provided to nonprofit health maintenance organizations under the Health Maintenance Organization Act of 1973,42 U.S.C. $\$ \$ 300 \mathrm{c}-2$ to $300 \mathrm{c}-$ 8 (1974 \& 1981 Supp.). Devices of this sort might well be superior to tax exemption as a means of allocating capital to the nonprofit sector-though such bureaucratic mechanisms for distributing capital can be quite costly to administer and are subject to constraints and influences that may result in an allocation that is far from efficient.

In any case, the question at hand is not whether it might be possible to design a mechanism for allocating capital to the nonprofit sector that would be superior to tax exemption, but whether, given that no such alternative mechanism is in place, granting tax exemption to certain classes of nonprofits is better policy than not granting such exemption. 
dom of the current policy of taxing, at corporate rates, the income that nonprofits derive from such investments in unrelated industries. On the other hand, the analysis offered here provides an appropriate starting point for viewing this issue. ${ }^{114}$

Further, this analysis of income tax exemption does not extend directly to the exemption of nonprofits from other types of taxes, such as property taxes and sales taxes. Since exemptions from these latter taxes actually have the effect, in contrast to income tax exemption, of reducing factor costs at the margin for nonprofits below the marginal costs facing forprofit firms, such exemptions have subsidy effects that are not to be found with the income tax exemption. The capital subsidy justification offered here for exemption from the corporate income tax can be extended, however, at least in general terms, to exemption from property taxation.

\section{Mutual Nonprofits}

The discussion so far has proceeded on the implicit assumption that the nonprofit organizations in question are "entrepreneurial" nonprofits;"15 that is, are under the control of managers who are relatively autonomous. The great majority of nonprofits of any financial significance are, in fact, of this type. In particular, it is quite common for ultimate authority over the affairs of a nonprofit corporation to be vested, by the corporation's charter, in a board of directors that is self-perpetuating and responsible to no other group.

Some nonprofits, however, are formed as membership organizations in which the board of directors is elected by the organization's patrons (that is, the individuals who are the ultimate source of the organization's income: customers in the case of commercial nonprofits, and donors in the case of donative nonprofits). Such membership organizations are conveniently referred to as "mutual" nonprofits, to distinguish them from entrepreneurial nonprofits. ${ }^{116}$

\section{A. Do Mutual Nonprofits Raise Special Issues?}

In general, the analysis offered throughout this Article applies to mutual as well as to entrepreneurial nonprofits. This is particularly true of donative mutual nonprofits, such as the National Audubon Society; the mere fact that the donors who support the Society also have voting control

114. Investments in unrelated businesses provide another mechanism, in addition to that discussed at pp. 78-79 supra, by which the managers of a nonprofit can trade off present for future production of the nonprofit's services. The rate at which such investments are taxed governs the terms of that tradeoff.

115. The term derives from the classification introduced in Hansmann, supra note 2, at 840-42.

116. For a general discussion of mutual nonprofits, see id. at 841-42, 890-94. 
over it does not appear to give the Society notably better access to capital than, say, the March of Dimes, which is an entrepreneurial donative nonprofit. The same is true of many mutual commercial nonprofits. For example, Consumers Union is essentially a mutual commercial nonprofit; its income comes entirely from the sale of Consumer Reports magazine and other items that it publishes, and control over the organization is lodged in the magazine's subscribers, who have the authority to elect the board of directors. Yet it is not obvious that, simply because Consumers Union is a mutual nonprofit, it has better (or worse) access to capital than does the National Geographic Society, another commercial nonprofit publisher (which derives most of its income from the publication of National Geographic magazine), but one that happens to be organized as an entrepreneurial rather than as a mutal nonprofit.

To be sure, there are some types of commercial mutual nonprofits for which the capital constraint justification for income tax exemption seems weakened simply because the organizations in question are mutual rather than entrepreneurial nonprofits. Social clubs, such as country clubs, provide an example. The members of such clubs are often themselves a reasonably adequate source of capital. The members frequently have a longstanding relationship with the club, use the club's facilities relatively intensively, and are involved in the governance of the club. Thus they are presumably more likely to see the need for, and to be willing to respond to, the club's need for capital contributions through initiation fees, special assessments, or dues in excess of what is needed to meet annual operating costs.

Such reasoning is arguably sufficient to justify denying tax exemption to social clubs and similar organizations. Yet it is probably unnecessary to rely heavily on the persuasiveness of this logic alone in assessing the wisdom of granting tax exemption in such cases. Social clubs and related organizations are anomalies of a sort in the world of nonprofits. The services that they provide do not seem to be characterized by contract failure, and hence they do not seem to need the strict nondistribution constraint that properly characterizes the nonprofit form. ${ }^{117}$ In many or most cases, in fact, they would arguably be organized more appropriately as consumer cooperatives, ${ }^{118}$ which do not suffer from handicaps in obtaining capital of the same severity as those that confront nonprofits. ${ }^{119}$ It follows that income tax exemption could appropriately be denied to nonprofit social

117. See id. at 892-94.

118. See Hansmann, supra note 12 , at 587-95.

119. For example, cooperative corporations, in contrast to nonprofit corporations, typically have the authority to sell shares of capital stock upon which dividends can be paid, although there is usually a statutory ceiling on the rate of return that can be paid on such stock. See Hansmann, supra note 2 , at 889 . 
clubs on the ground that they fail the test of relative efficiency suggested in Section IX.B. That is, nonprofit corporations are not conspicuously more efficient producers of the services typically provided by social clubs than are cooperative corporations (or perhaps even business corporations), and therefore nothing is gained by granting them an exemption from income taxation in order to help overcome the capital constraints they must face when utilizing the nonprofit corporate form.

Under current law, contrary to the position suggested here, income tax exemption is extended to social clubs and various similar mutual commercial nonprofits. ${ }^{120}$ This contrasts with the treatment afforded cooperatives, which, in general, are taxed like ordinary business corporations. ${ }^{121}$

\section{B. Mutual Nonprofits and Cooperatives as Household Production}

Although Bittker and Rahdert also consider nonprofits such as social clubs to be analogous to consumer cooperatives, they conclude from this analogy that both social clubs and ordinary consumer cooperatives should be exempted from income taxation. ${ }^{122}$ Their argument, in essence, is that in such organizations individuals are simply banding together to provide services for themselves collectively. Since we do not tax individuals on household production that they use directly for their personal consumption, such as leisure activity and home-grown vegetables, it is inconsistent to levy a tax on the proceeds resulting when individuals band together, in a nonprofit or a cooperative corporation, to produce services for themselves. In other words, if we do not tax an individual on the (imputed) return he receives from his private backyard tennis court, why should we levy a tax on the proceeds from a tennis club that he and his neighbors form? Is not such a club just an extended form of household protection?

There is some force to this argument. So long as we tax the nonprofit or cooperative club, we create a bias in favor of individual household production in contrast to provision of the same service through mutual organizations that may well be more efficient. However, a similar argument cuts the other way. For as long as we exempt, say, tennis clubs organized as nonprofit or cooperative corporations, we create a bias in favor of tennis clubs that are organized in this fashion as opposed to tennis clubs that are organized as proprietary businesses. But it is not immediately apparent that there is a principled reason for imposing a tax on the return to capital in a tennis club in which the investors of capital and the customers

120. I.R.C. $\S 501(\mathrm{c})(7)$.

121. I.R.C. $\$ \S 1381-1388$. Patronage dividends are, however, deductible by a cooperative in figuring its taxable income, evidently on the theory that such dividends simply constitute a refund of part of the price paid for the organization's services. Id. $\S 1382$.

122. Bittker \& Rahdert, supra note 1 , at $348-53,358$. 
are different people (as is likely to be the case if the club is formed as a business corporation), but not when the investors of capital and the customers are the same group of people (as is likely to be the case if the club is organized as a (mutual) nonprofit corporation or as a cooperative corporation).

\section{Tax Bias In General}

The essence of the problem here, of course, is that our current system of federal income taxation imposes differential burdens on productive activity according to the way in which that activity is organized. Household production is taxed differently than production undertaken through proprietorships and partnerships, and the latter in turn is taxed differently than production undertaken through the form of the business corporation. The result is that the choice among these organizational forms is biased by the tax system. If these features of the tax system are to be taken as given, how then should we tax nonprofit (or cooperative) corporations? Any answer we choose will create biases in the choice of the nonprofit form as opposed to other legal forms for organizing activity. The argument that runs through this Article is that it makes sense to tax nonprofits in such a way that these biases tend to offset other allocational biases-such as imperfect access to capital-inherent in the organizational forms involved. And on the basis of this principle, it has been suggested here, a case can be made out for granting income tax exemption to many nonprofits, but not to others-including, perhaps, social clubs.

\section{Conclusion}

It has been suggested here that the exemption of nonprofit organizations from federal income taxation should not be viewed simplistically as a subsidy for good works or as a natural consequence of the tax base to which the corporate income tax is applied. Rather, the exemption should be viewed in terms of its consequences for capital formation in the nonprofit sector. Seen in this light, the justification for the exemption is less clear-cut than has commonly been supposed, though it is still possible to rationalize current policy in this area, at least in its broad outlines. 


\section{APPENDIX: A SIMPLE MODEL}

The relatively informal discussion in the text can be illustrated and clarified by a simple mathematical model.

Consider an industry in which for-profit firms (denoted by the superscript "f") can produce in each period (e.g., year) $i$ an amount $Q f$ of their product, using inputs capital, $\mathrm{K}_{\mathrm{f}}^{\mathrm{f}}$, and labor, $\mathrm{L}_{\mathrm{i}}$, via a constant returns to scale production function $Q_{1}=F\left(K_{1}^{f}, L f\right)$. Assume also, for simplicity, that the capital-labor ratio for this technology is fixed at $K_{\mathrm{f}} / \mathrm{L}_{\mathrm{i}}=\mathrm{k}^{123}$ Nonprofit firms in this industry (denoted by the superscript " $n$ ") produce according to the same fixed-proportions technology except that for such firms $Q_{1}^{n}=\gamma F\left(K_{i}^{n}, L_{i}^{n}\right)$, where $\gamma$ may be greater or less than unity (i.e., nonprofit firms may produce more or less efficiently than forprofit firms). The factor $\gamma$ here is intended to reflect the balance of (a) the advantages that nonprofits may have over for-profit firms due to contract failure, and (b) the special disadvantages that nonprofits may suffer due to, for example, the reduced incentives for cost minimization that derive from the inability of the organizations' managers to appropriate the resulting cost savings.

The industry's product sells at a price $P_{i}$ that is a declining function of the total industry output from nonprofit and for-profit firms, denoted by $Q_{i}$. Labor must be paid a (constant) wage $w$ by both nonprofit and for-profit firms. Capital, which does not depreciate, must be compensated at an annual rate of at least $r$ if it is obtained in the market. For-profit firms obtain all of their capital in the form of equity rather than debt. ${ }^{124}$

Assume that nonprofit firms cannot obtain capital on the market in the form of either debt or equity. Rather, each nonprofit firm begins with an initial endowment of gift capital, upon which it need pay no return. Thereafter, a nonprofit firm can obtain additional capital only by purchasing it with the firm's net earnings. The price of capital is assumed to be unity. Thus, if a nonprofit begins year $i$ with a capital endowment $K_{1}^{n}$, it can increase its capital stock at the end of year $i$ by an amount

$$
\mathrm{dK}_{\mathrm{i}}^{\eta}=\mathrm{P}_{\mathrm{i}} \mathrm{Q}_{\mathrm{i}}^{\mathrm{n}}-\mathrm{wL}_{\mathrm{i}}^{\eta}=\mathrm{P}_{\mathrm{i}} \mathrm{Q}_{\mathrm{i}}^{\mathrm{n}}-\mathrm{wK}_{\mathrm{i}}^{\mathrm{n}} / \mathrm{k} \text {. }
$$

The capital available to the firm in year $\mathrm{i}+1$ will then be $\mathrm{K}_{\mathrm{i}+1}^{\mathrm{n}}=\mathrm{K}_{\mathrm{i}}^{\mathrm{n}}+\mathrm{dK}_{\mathrm{i}}^{\mathrm{n}}$.

123. With these assumptions, the production function $F(K, L)$ here has the form $F(K, L)=$ $\min [\alpha \mathrm{K}, \beta \mathrm{L}]$, where $\alpha$ and $\beta$ are constants satisfying $\beta / \alpha=\mathrm{k}$.

124. This assumption is not entirely harmless. If for-profit firms are able to obtain all of their capital, or simply their marginal capital, in the form of debt, then the corporate income tax will have no effect on the before-tax rate of return that the frms must earn on their capital, since interest payments on debt are deductible under the corporate income tax. In this case, the corporate tax becomes a tax, not on the return to capital, but rather on pure profits earned by corporations (or perhaps on entrepreneurship, or on the efficiencies provided by the corporate form as opposed to other business forms that are not subject to the tax). This is essentially the argument offered by Stiglitz, supra note 10.

The model developed here and the discussion that appears at p. 77 supra remains valid so long as equity investment is necessary simply to obtain marginal capital-i.e., so long as a firm cannot obtain 100\% debt financing. Presumably the arguments in note 67 supra concerning the impracticability of $100 \%$ debt financing apply to for-profit as well as nonprofit firms, and, therefore, it is not unreasonable to assume that this is the case.

In any case, as discussed in Section VIII.E supra, the basic conclusions are not affected if we accept Stiglitz's view of the corporate income tax (as applied to for-profit firms) as a tax only on pure profits. 
Because a nonprofit cannot distribute its net earnings, and because here, as in the text, we shall ignore the possibility that a nonprofit might invest its net earnings in the securities of other firms (e.g., build an endowment), it follows that a nonprofit has no alternative but to spend its net earnings on additions to its capital stock.

The managers of nonprofit firms operate the firms in a fashion that maximizes an objective function $U=U\left(Q_{1}^{n}, Q_{2}^{n}, \ldots\right)$, with $\partial U / \partial Q_{1}^{n}>0$ for all $i$. Any objective function of this type will generate the same behavior for the nonprofit firms in this model, since the assumption of a fixed capital-labor ratio eliminates the opportunity for trading off lower production in one period for greater production in another. This implies that the "indirect effects" of exemption discussed in the text do not show up in this model. ${ }^{125}$

\section{A. For-Profit Firms Only}

Consider first a competitive industry in which there are only for-profit firms. If there are no taxes, then the industry will expand to the point where

$$
P_{i} Q_{i}=P_{i} Q_{i}^{f}=P_{i} F\left(K_{i}^{f}, L_{i}^{f}\right)=w L_{i}^{f}+r K_{i}^{f} \text {, }
$$

which is the efficient level of production. If, alternatively, returns to (equity) capital and pure profits are taxed at a rate $t$, as under the corporate income tax, then the industry will expand only to the point where $\mathrm{rK}_{\mathrm{i}}^{f}=\left(\mathrm{P}_{\mathrm{i}} \mathrm{Q}_{\mathrm{i}}^{\mathrm{f}}-\mathrm{wL} \mathrm{L}_{\mathrm{i}}\right)(1-t)$, and hence $P_{i} F\left(K_{i}^{f}, L_{i}^{f}\right)=w L_{i}^{f}+[r /(1-t)] K_{i}^{f}$.

\section{B. Nonprofit Firms Only}

Consider now an industry in which there are only nonprofit firms. In the absence of taxes, and because capital does not depreciate, the firms will expand until the price for their service has dropped to the point where $P_{i} Q_{i}=P_{i} Q_{i}^{n}=$ $P_{i} \gamma F\left(K_{i}^{n}, L_{i}^{n}\right)=w L_{i}^{n}$. That is, the price falls to the point at which capital earns a zero net rate of return, and there is excessive production of $Q_{i}$, given the nonprofits' production function.

Alternatively, if nonprofits are taxed on their net earnings at a rate $t$, they will still expand production to the point where net earnings are zero, i.e., where $P_{i} Q_{i}^{n}$ $=w_{\mathrm{i}}$. With the tax, however, the firms will expand to this point at a rate that is only (1-t) as rapid as it would be in the absence of the tax.

\section{Both Nonprofit and For-Profit Firms}

Finally, consider an industry that initially is populated only by for-profit firms, and that is operating at the for-profit equilibrium price $\overline{\mathrm{P}}_{\mathbf{i}}$ that satisfies the condition.

$$
\text { (1) } \bar{P}_{\mathrm{i}} \mathrm{F}\left(\mathrm{K}_{\mathrm{i}}^{\mathrm{f}}, \mathrm{L}_{\mathrm{i}}^{\mathrm{f}}\right)=\mathrm{wL}_{\mathrm{i}}^{\mathrm{f}}+[\mathrm{r} /(\mathrm{l}-\mathrm{t})] \mathrm{K}_{\mathrm{i}}^{\mathrm{f}} \text {. }
$$

Suppose, then, that a nonprofit firm seeks to enter the industry. In order to

125. See p. 78 \& note 75 supra. 
survive and grow, the nonprofit, whether it is tax exempt or not, must be able to more than cover its labor costs at the prevailing market price $\overline{\mathrm{P}}_{\mathbf{i}}$ for its product. That is, it must be the case that, for the nonprofit,

$$
\text { (2) } \overline{\mathrm{P}}_{\mathrm{i}} \gamma \mathrm{F}\left(\mathrm{K}_{\mathrm{i}}^{\mathrm{n}}, \mathrm{L}_{\mathrm{i}}^{\mathrm{n}}\right)>\mathrm{wL}_{\mathrm{i}}^{\mathrm{n}}
$$

Will (2) be satisfied at the market price $\overline{\mathrm{P}}_{\mathrm{i}}$ determined by (1)? Given the assumption of fixed factor proportions $\left(\mathrm{K}_{\mathrm{i}} / \mathrm{L}_{\mathrm{i}}=\mathrm{k}\right.$ for both nonprofit and for-profit firms) and constant returns to scale, condition (1) must hold for the factor amounts $\left(K_{\mathrm{i}}^{n}, L_{i}^{n}\right)$ used by the nonprofit firm, so that we have

(3) $\overline{\mathrm{P}}_{\mathrm{i}} \mathrm{F}\left(\mathrm{K}_{\mathrm{i}}^{\mathrm{n}}, \mathrm{L}_{\mathrm{i}}^{\mathrm{n}}\right)=w_{\mathrm{i}}^{\mathrm{n}}+[\mathrm{r} /(1-\mathrm{t})] \mathrm{K}_{\mathrm{i}}^{\mathrm{n}}$.

Solving (3) for $\overline{\mathrm{P}}_{\mathrm{i}}$ and substituting into (2), we have

(4) $\left.\gamma_{w} L_{i}^{n}+\gamma[r /(l-t)] K_{i}^{n}\right)>w L_{i}^{n}$.

Setting $L_{i}^{\eta}=K_{i}^{n} / k$, we see that (4) will be satisifed if and only if

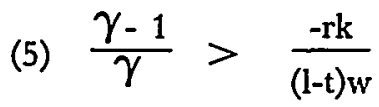

Because the right-hand side of (5) is negative, this condition obviously holds if $\gamma>1$, i.e., if the nonprofit is more efficient than the for-profit firms. It also holds, however, for a range of values of $\gamma$ less than unity. Moreover, the higher the tax rate $t$, the lower the level of efficiency $\gamma$ at which the nonprofit can survive and grow.

Note that if condition (5) is satisfied, nonprofit firms will continue to expand until they have driven $P_{i}$ below the level $\overline{\mathrm{P}}_{\mathrm{i}}$ that satisfies (1). For-profit firms will then suffer losses and leave the industry, which will continue to expand, with only nonprofit firms, to the all-nonprofit equilibrium point where $P_{i} \gamma F\left(K_{i}^{n}, L_{i}^{n}\right)$ $=\mathrm{wL}_{\mathrm{i}}^{\mathrm{n}}$.

\section{Policy Implications}

In this simple model, the exemption of nonprofit organizations from taxation leaves the long-run competitive equilibrium between nonprofit and for-profit firms unchanged. The result of the exemption is simply to allow nonprofit firms to expand more quickly toward their long-run equilibrium.

The efficient level of development for nonprofit firms in any industry, whether or not they face for-profit competitors, is roughly that point at which their return to capital equals the opportunity cost of diverting that capital from the (presumably dominant) profit-seeking sector. That point is, if $\gamma \geq 1$, where

$$
\text { (6) } \mathrm{P}_{\mathrm{i}} \gamma \mathrm{F}\left(\mathrm{K}_{\mathrm{i}}^{\mathrm{n}}, \mathrm{L}_{\mathrm{i}}^{\mathrm{n}}\right)=\mathrm{wL}_{\mathrm{i}}^{\mathrm{n}}+[\mathrm{r} /(\mathrm{l}-\mathrm{t})] \mathrm{K}_{\mathrm{i}}^{\mathrm{n}} \text {. }
$$

If $\gamma<1$, the efficient level of output from nonprofits is zero. This corresponds to a level of output for nonprofits that is typically less than the output in their longrun equilibrium.

The efficient policy, therefore, is to grant exemption to nonprofits only in industries in which (a) $\gamma>1$ (i.e., nonprofit firms are more efficient than for-profit firms), and (b) the level of output among nonprofits falls short of the output level 
that satisfies condition (6).

Of course, these conclusions are to some extent dependent upon the various restrictive assumptions that have been used in this model, such as a fixed capital/ labor ratio, the unavailability of debt capital, and so forth. The consequences of relaxing these assumptions are explored in the text and footnotes of the body of the article. 


\section{The Yale Law Journal}

Volume 91, Number 1, November 1981

\section{David Wippman}

Editor-in-Chief

\author{
Randall Kennedy \\ Note \& Topics Editor \\ Richard Bartlett \\ George C. Harris \\ Robert Silver \\ George Wyeth \\ Note Editors
}

\author{
Ellen R. Porges \\ Managing Editor \\ Tim Atkeson \\ Russell Hayman \\ Jonathan R. Macey \\ Theodore A. Paradise \\ Alan O. Sykes \\ Article \& Book Review Editors
}

\begin{abstract}
Kathleen Cully
Robert D. Gilbert

Charles Glick

Mark A. Goldberg

Candice Hoke
\end{abstract}

Steven Gunby
Rick Levy

David R. Lewis

John Lewis

Rory K. Little

Senior Editors

Noel V. Lateef

Hector Torres

Editors
Jonathan E. Richman Alfred O. Rose

Dieter Snell

Lynn A. Stout

Monique Witt

John Motulsky

Business Manager: Pamela Standish

Editorial Assistant: Liz Doyle

Editorial Assistant: Gail Kalison

\section{Student Contributors to This Issue}

Jonathan R. Macey, A Conduct-Oriented Approach to the Glass-Steagall Act

Ellen R. Porges, Protecting the Public Interest in Art

Jonathan E. Richman, Facial Adjudication of Disciplinary Provisions in Union Constitutions

Alan O. Sykes, An Efficiency Analysis of Vicarious Liability Under the Law of Agency 